NCBI Bookshelf. A service of the National Library of Medicine, National Institutes of Health.

Reinisch J. The Perils of Peace: The Public Health Crisis in Occupied Germany. Oxford (UK): OUP Oxford; 2013 Jun 6.

\title{
Chapter 7 Public Health Work in the Soviet Occupation Zone
}

\section{Plans}

Throughout the war the Soviet Union took part in meetings and summits with the United States and the United Kingdom, which produced agreements on the general premises of the occupation: the NSDAP and its affiliated organizations were to be disbanded; perpetrators of war crimes were to be tried; and Nazis were to be removed from positions of influence. The Soviet Union signed up to these basic pillars of Allied policy even though their interpretations of Nazism differed significantly from the other occupiers. Soviet officials, unlike their British, American, and French colleagues, identified the Nazi regime as a product of the crisis of monopoly capitalism, rather than as a mass movement, a reflection of German militaristic culture, or a psychiatric condition. So although the occupiers could agree on depriving the Junker landlords and industrial elites of their position and influence, they did so for different reasons: the British, Americans, and French saw the Junkers as the embodiment of the Prussian militarist mentality; the Soviets saw them as representatives of the capitalist ruling class. In the Soviet zone, Junker estates were to be expropriated and divided in radical land reforms, and their industrial establishments were to be nationalized; while the working classes were to be given the means for recovery and revival. ${ }^{1}$

On some issues, the occupiers' public agreement on the treatment of Germany thus disguised significantly different priorities. The bulk of Soviet wartime preparations prioritized military security and Soviet reconstruction through German reparations. The Soviet demand for substantial reparations, in particular, handicapped the occupiers' relationships; the wartime conferences had failed to settle their differences. In the absence of quadripartite agreements the Soviets simply made their own arrangements. In late 1944 Georgy M. Malenkov was put in charge of a Committee for the Rehabilitation of the Economy of Liberated Areas (based in Moscow), to oversee the extraction of reparations and dismantling operations. They were represented in Germany by Maxim Z. Saburov. ${ }^{2}$ Anastas I. Mikoyan, deputy chair of Sovnarkom (the Council of People's Commissars, later USSR Council of Ministers) and people's commissar for foreign trade, tracked the transfers of equipment and capital to the Soviet Union. By May 1945, the committee supervised an operation of around 70,000 officials in the Soviet zone, most of them in uniform and with officer's rank. ${ }^{3}$ With Soviet dismantling teams already at work, the Potsdam conference in July 1945 could only confirm existing disagreement: the Soviet delegation, accompanied by their economic adviser Eugen Varga (the economist discussed in Chapter 2), demanded reparations of 10 billion dollars; the Western Allies rejected this. In the end it was resolved that each occupier would meet their reparation demands through removals from their own zone, and the Soviet Union was to receive 25 per cent of any dismantled industrial plants from the western zones (partly in exchange for food and raw materials). ${ }^{4}$ The absence of the French at the early planning stages weakened the Soviet position, as they, seeking reparations of their own, would have been useful allies.

No less significant than strained relationships with the other occupiers were clashes between different factions within the Soviet authorities. Historians of the Soviet Union have been fascinated by domestic conflicts between its leading officials, although some rightly question the available sources and conclusions about Soviet policy we can legitimately draw from them. ${ }^{5}$ Nevertheless, there is clear evidence of competing occupation strategies. At one end stood advocates of a moderate foreign policy to build a neutralized, antifascist, united Germany, along with the Western Allies; at the other end stood supporters of a radical programme to turn Germany into a communist, 'Sovietized' satellite. The question of reparations figured centrally in both.

The more moderate political line, which dominated until 1946, was accompanied by a policy of extensive and prompt reparations, and a radical deindustrialization of Germany. Supporters included the members of the influential State Defence Committee, created days after the German invasion in 1941: Vyacheslav Molotov, people's commissar for foreign affairs; Lavrenti P. Beria, people's commissar for internal affairs and deputy chair of Sovnarkom; Georgy Malenkov, in charge of the Reparations Committee; and Molotov's deputy, Clement E. Voroshilov. Beria, Malenkov, and others anticipated that all Allied forces would eventually withdraw from Germany, and thus argued for the seizure and transportation of German assets from the zone to the Soviet Union while that was still possible; speed was essential. In Germany this policy was supported by leading members of the Soviet Military Administration in Germany (SMAG), including Marshall Zhukov's deputy and chief Soviet representative on the Allied Control Council (ACC), Vasily D. Sokolovsky, and Zhukov's first adviser and future Soviet high commissioner in Germany, Vladimir S. 
Semyonov. They opposed an immediate Sovietization of Germany or the creation of a satellite state, and supported extensive reparations and dismantling operations to aid Soviet reconstruction. 6

But political and economic priorities came increasingly into conflict: seizing factories and goods would benefit Soviet reconstruction, but undermine the credibility of a Moscow-supported government in the zone. As a result, Andrei A. Zhdanov, member of the Politburo and secretary of the Central Committee's departments for foreign policy and culture, supported a more radical political programme and a more cautious economic approach. When the Reparations Committee was established during the war, Zhdanov was among those to favour an economic recovery in the Soviet zone, and the payment of reparations through current production rather than radical dismantling. Zhdanov later became known for the 'two camps' doctrine, enunciated at the inaugural conference of the Communist Information Bureau (Cominform) in September 1947, where the post-war world was divided into a capitalist, imperialist camp, led by the United States, and a socialist camp, led by the Soviet Union. According to this perspective, the solution to the German problem was the creation of a communist Germany (or portion of it), which would be hampered by the removal of industry. In Germany, Zhdanov's approach was represented by Sergey Tiulpanov, who, from summer 1945, headed the SMAG's Department for Agitation and Propaganda.

The conflict between these very different strategies soon affected the work of public health officers, both Soviet and German. But in May 1945, the most important feature of the Soviet occupation brief was that for many problems no plans were made at all. Throughout the war, Stalin and his commanders were reluctant to focus on the occupation before Germany had been defeated; military operations took priority. Additional disorientation stemmed from the fact that Stalin's analyses of the big political decisions, as far as they were known, continually 'zigzagged' in response to events. ${ }^{7}$ In 1941 Stalin reportedly intended to divide Germany into several independent states, separating Prussia from the rest. ${ }^{8}$ In February 1943 he opposed this strategy, only to support it again at the Teheran conference in November 1943. At Yalta in February 1945, Stalin opposed dismemberment but favoured a division into occupation zones. At Potsdam he agreed to treat Germany as a single economic unit run by the ACC. It was clear only that Stalin, like his foreign minister and spy chief, was interested in a policy which granted security and extensive reparations - but this could mean very different tactics and strategies. ${ }^{9}$ Historians still disagree about Soviet motives in Germany—whether a Soviet reorientation of Germany was always intended, or whether it was a reaction to American initiatives such as the Marshall Plan. Those writing at the height of the Cold War were certain about the far-sighted nature of Soviet aims, but more recent work portrays Soviet policies as reactive and piecemeal, rather than proactive and systematic. But even those who identify a clear political strategy in the Soviet occupation tend to agree that, apart from France, the Soviet Union was the least prepared and showed most inconsistencies in their occupation policy. 10

In the light of such uncertainties, Soviet planners shelved many issues, from the recruitment of officers to concrete policies on practical problems, until after the war. Sergey Tiulpanov later wrote that the Soviet government did not possess a 'fleshed-out "theory of occupation administration", or military government, only of liberation and German defeat: its work in Germany was guided by 'general principles of Marxist-Leninist theory and by the nature of the Second World War, which was an antifascist war of liberation even for the German people'. ${ }^{11}$ Georgy Zhukov agreed in his memoirs that Soviet troops came completely unprepared, particularly compared to the well-briefed and welltrained troops in the West. ${ }^{12}$

This did not mean that the Soviet military had no experience in military government. During the war they had acquired practical experience in the constitution and running of the Allied Control Commissions in Bulgaria, Hungary, Romania, and Finland. In addition, a cadre of experts who had participated in the incorporation of the Baltic Republics and the Western Ukraine into the Soviet Union, took positions in the SMAG. Among them was Ivan A. Serov, who in 1939 had been people's commissar for internal affairs in the Ukrainian Soviet Republic, and during the war had overseen some of the forced population movements and deportations within the Soviet Union. From June 1945 to February 1947 Serov was deputy chief of the SMAG with responsibility for civilian administration, and head of the zone's secret service. Another person with considerable experience was Vladimir S. Semyonov, who in 1939 had been an adviser to the Soviet administration in Lithuania, and in 1945 became a political adviser to the SMAG, where he later ran his own department. And there was Andrei Y. Vychinsky, who had, as deputy foreign minister of the Soviet Union, taken part in the Allied Control Commission for Italy, and became Zhukov's First Political Adviser. ${ }^{13}$ Drawing on their recommendations, the Soviet State Defence Committee issued the first general directives for the administration of the territories occupied by Soviet troops in April 1944, but none made any particular recommendations for Germany. Only directives from January and April 1945 provided any details about the organization of military headquarters in Germany, and many details were still missing even there. ${ }^{14}$ 
As shown in Chapter 2, the Soviet authorities were eager to supplement their patchy plans and threadbare directives with preparations from the other occupiers. Anglo-American plans for the structure, organization, and administrative divisions of military government, and the training of officers were repeated in Soviet directives, particularly after March 1945, when the Americans made available their military government handbooks. ${ }^{15}$ These details helped to establish the administrative and structural parameters of the occupation apparatus - which broadly mirrored the German government's ministerial divisions, and was to be controlled by 'indirect rule'. The extremely low staff allocations in spring 1945, of only 125 people to the entire SMAG, ${ }^{16}$ stemmed not only from a lack of resources and a radical underestimation of the extent of Soviet involvement in German affairs, but also from copying Anglo-American preparations. SHAEF directives and manuals emphasized that the Allies were to supervise, oversee, and control, not to do the required jobs themselves. The Soviet authorities, like the British and Americans, underestimated the number of staff required.

The other occupiers' preparations filled some of the gaps in the Soviet government's plans. Others, as seen in Chapters 3 and 4, were filled by German communist émigrés in Soviet exile, which had a particular impact on public health. The Soviet authorities' lack of direction on many day-to-day issues dictated that the émigrés were enlisted wherever possible ${ }^{17}$ - arguably a form of 'indirect rule' in practice. Germans active in the orbit of the German Communist Party (KPD) in exile, the National Committee Free Germany (NKFD), and in various Soviet political, educational, and military institutions, busily prepared for post-war Germany by drawing up lists of cadres to be appointed and urgent tasks to be carried out. Given their lack of resources and trained personnel, the Soviet authorities often had few options other than to rely on émigrés. They did not have the capacity to govern their part of Germany on their own.

The 'Guidelines for the Work of the German Antifascists in the Territories Occupied by the Soviet Army', drafted by the Moscow KPD group in April 1945, are a useful example. ${ }^{18}$ This six-page document listed some of the most important tasks, and had important advice for the Soviet authorities in areas controlled by the Red Army. Apart from the urgent need to reactivate the media (radio stations, newspapers, and publishing houses for 'progressive literature'), the main priority was to establish administrative organs, to be staffed by the native population. Local officials would then carry out and oversee the most urgent tasks: the organization of basic health and hygiene measures, the distribution of food, the allocation of housing, the control of utilities (gas, water, electricity, and transport), the health service, as well as education (training, libraries, and schools), banking, and trade. Soviet commanders (assisted by the German émigrés) were to identify and appoint suitable mayors, who could then assemble and preside over local authorities, ideally containing at least ' 5 to 7 antifascists'.

German antifascists were valuable assets, the authors of this document insisted: some would be most useful if based at Soviet army headquarters, overseeing the publication of newspapers and the resumption of radio broadcasts to pacify and educate the local population, and prevent skirmishes with Soviet troops; others could assist in the recruitment of reliable and trustworthy locals, and 'ensure that the newly created organs contain reliable antifascists and really work within the guidelines'. ${ }^{19}$ They would be most useful to the Soviet troops by establishing networks of 'trusted persons' (Vertrauensleute). Using their knowledge of local personalities and political organizations, the émigrés would be able to recruit dependable, politically reliable individuals to oversee initiatives in their villages, streets, factories, and apartment blocks - and Soviet commanders could communicate with the German population through them and ensure the local population's compliance. With the help of 'trusted persons', the émigrés would be able to identify leading Nazis, and even begin to register all former members of the NSDAP, and those who had fought in the Wehrmacht and the Volkssturm.

These guidelines, and similar documents, were categorical about the criteria by which 'trusted persons' could be identified: those Germans who before 1933 had been involved in antifascist organizations, and had 'remained steadfastly opposed to the Hitler regime', were the best candidates for key jobs. They were likely to be 'workers' who had been opposed to Nazi rule. Soviet commanders and their German aides were also encouraged to make contact with 'responsible forces from the ranks of the intelligentsia who are capable of further development and who did not belong to the Nazi Party or Hitler Youth'. In addition, the authors thought it was worth checking 'who, from those intellectuals, engineers, doctors and teachers who had joined the Nazi Party in the last war years, but who had not carried out any active work within it, could be made use of'. A sentence stating that the wives of Nazi Party members should not be utilized was crossed out in the April 1945 draft. $^{20}$ Similar compromises were forced onto the British and Americans in the post-war years. The émigrés, trying to act as intermediaries between the Soviet occupiers and the German population, seem to have arrived at similar conclusions, but rather earlier. 
The KPD in exile ran a series of re-education courses for German POWs. The NKFD — one of the German émigré groups featured in Chapter 3-was central to initiatives to persuade German soldiers to surrender and to re-educate them in captivity. As Khrushchev recalled in his memoirs, Walter Ulbricht and his associates actively carried out 'antifascist propaganda, using loudspeakers along the front lines and calling on the German troops to surrender. This work was carried out mainly at night. Ulbricht would crawl along the front lines with his loudspeakers, directing his message to the soldiers and officers of [Field Marshall] Paulus' army group. Ulbricht and I always ate together, and I joked with him: "Well, what is this, Comrade Ulbricht? You haven't earned your daily bread today. No one surrendered." He calmly continued what he was doing. ${ }^{21}$ Paulus, who commanded the German Sixth Army's assault on Stalingrad in 1942, was one of the most prominent Germans to surrender. He joined the NKFD and its special organization for officers, the League of German Officers (Bund Deutscher Offiziere), and became a vocal critic of Nazi Germany. ${ }^{22}$

With backing from the Soviet government, Walter Ulbricht, Wilhelm Pieck, and Anton Ackermann organized training courses for hundreds of Germans in Soviet exile to prepare them for administrative work in Germany. Two-month training courses began in Nagornoye, near Moscow, in September 1944, before the Red Army had crossed the German border. By December 1945 five courses had taken place with around twenty-five to thirty participants on each. ${ }^{23}$ They supplemented training courses for Germans organized by the political administration of the Red Army (GlavPURRKA) and the party schools in Moscow. Together with Dimitrov, Manuilsky, and other senior Comintern personnel, Pieck, Ulbricht, and Ackermann also prepared and lectured on training courses for Soviet officers. Sergey Tiulpanov remembered that shortly before the Red Army crossed the borders of the Soviet Union, the German communists gave lectures about future tasks in the occupied territories. Elaborating upon resolutions of the 1935 Comintern congress, they talked about the need for communists to work with other antifascist forces. ${ }^{24}$

The émigrés also compiled lists of future administrators, which the Soviet authorities actively used. Around 2,500 Germans were employed by the political administration of the Red Army during the war, and many of them featured in staff lists for future political and administrative jobs. ${ }^{25}$ Wilhelm Pieck estimated that between 1 May and 10 June 1945, 275 German cadres from the KPD and the NKFD were sent into the Soviet zone. ${ }^{26}$ On their way they worked as translators, advisers, and general 'intermediaries'. After their arrival they often became mayors, district administrators, or officials themselves. ${ }^{27}$

\section{Compromises}

The immediate problems faced by Soviet troops were similar to those in the other zones. The German novelist Theodor Plievier, who travelled from Moscow to Germany in spring 1945, wrote that, after the bombing raids in February 1945, Dresden looked as though 'a giant plough had swept over the earth leaving behind a complete wreckage'. 'Nothing was left of the big hotels', he wrote, 'five or six had stood just there. In their place, wave after wave of rubble and masonry frozen into immobility. From the rubble emerged a column here; the arch of a window there; further away the shell of a split tower; a decapitated church; famous Dresden façades motionless in the middle of a general collapse, covered by soot and grime, strangely ghostlike. ${ }^{28}$ Dresden was an extreme physical reminder of the consequences of defeat, but it was not a unique sight in the new Soviet zone. Brandenburg and Mecklenburg in the north of the zone had also seen heavy fighting, and Berlin was a mess of rubble and devastation on an unbelievable scale - perhaps only equalled by the traces of the Germans' torching of Warsaw.

Soviet officers - like everyone else — were concerned about the potential for public health disasters. The bombing raids had destroyed urban facilities for coping with health problems; the parts of the hygiene infrastructure to escape the bombing then collapsed during the artillery attacks and street battles of the last weeks of the war. Conditions were dire in many parts, but nowhere were they more serious than in Berlin. The provision of clean water, electricity, and gas, and the collection of garbage had all stopped. Sewage spilled into rivers and lakes, and corpses piled up because they could not be buried fast enough. Flies, rats, mosquitoes, lice, and other disease carriers bred and multiplied. City inhabitants lived crowded together in cellars, bomb shelters, and underground tunnels, and were easy targets for spreading infections. Those hospitals not entirely destroyed overflowed with patients and the rapidly increasing stream of wounded soldiers and evacuees. There were acute shortages of doctors, drugs, beds, and medical apparatus. ${ }^{29}$

Berlin was a central destination in the vast population movements in Central and Eastern Europe in the last months of the war. German expellees made their way westwards, just as returned POWs and non-German displaced persons moved homewards and eastwards. Large numbers of people trekked through Berlin, either because they did not believe the rumours about the state of the capital, or because there was no other way they knew to go. Many of these people 
were malnourished, and had been exposed to typhus, dysentery, and typhoid fever. German health reports observed that typhus rates had increased rapidly and in direct relation to the numbers of refugees moving through refugee camps in Berlin. ${ }^{30}$ Just days after the war ended Berlin was gripped by an outbreak of diarrhoea. ${ }^{31}$ German and Soviet doctors were uncertain about whether it was an epidemic of dysentery or a more harmless outbreak of diarrhoea, but there were no facilities for the bacteriological identification of the disease agent, and no drugs or sera even if they could have identified it.

There was violence and looting in all zones by the victorious troops, but in the east it was of an entirely different scale. Military discipline among Soviet troops completely broke down in the last stages of the war. Soldiers proved impossible to control as they went on drinking, raping, and looting sprees during their advances through Eastern Europe, which only increased when they marched into German territory. ${ }^{32}$ The defeat of Berlin, in particular, was accompanied by an eruption of violence against, and rapes of, German civilians, peaking in the notorious fortnight of 24 April to 5 May, but it was endemic everywhere in the zone. Perhaps as many as one in three (of around 1.5 million) women in Berlin were raped at the end of the war. One estimate claims that in total almost 2 million German women were raped by members of the Red Army, many more than once. ${ }^{33}$ Commanders' attempts to punish their troops often proved futile, and they were only able to regain control weeks, sometimes months, later.

Official Soviet directives spelled out that the German people, especially its working classes, were not to be equated with the leaders of the Third Reich, and instructed Soviet troops to treat the German population accordingly. The Soviet High Command's April 1945 'Directive on the Treatment of the German Civilian Population', ordered troops to moderate their behaviour, since brutality would only lead to greater German resistance and prolong the war, bloodshed, and expense. 'A more humane attitude towards the Germans', the directive stated, 'will ease our warfare on their territory and will without doubt reduce the doggedness of the German defence.' It urged commanders to appoint German mayors and to create German administrations, and it directed them not to seek retribution against ordinary members of the NSDAP, if they appeared loyal enough to the Red Army. ${ }^{34}$

These instructions completely failed to contain the Soviet troops' hatred of Germans. Soldiers had marched through countless villages and towns (often their own) destroyed by the Wehrmacht. They had also been exposed to accounts, such as by the writer and journalist Ilya Ehrenburg, of what the Red Army had found at Maidanek, Auschwitz, and the other German-run 'death factories'. ${ }^{35}$ In an effort to boost morale, Ehrenburg had incited revenge and the desire to hold the Germans to account. One of his best known articles was simply entitled 'Kill!':

We have understood: the Germans are not people. From today on the word 'German' for us is the most frightful curse. From today on the word 'German' discharges rifles. We will not speak. We will not be indignant. We will kill. If, during the day, you have not killed a single German, your day has been in vain. If you believe that your neighbour will kill a German for you, you have not understood the menace. If you do not kill the German, the German will kill you. He will take your loved ones to his accursed Germany. If you cannot kill the German with a bullet, kill the German with a bayonet. If on your sector there is a lull, if you are waiting for the battle, kill the German before the battle. If you let the German live, the German will hang a Russian man and violate a Russian woman. If you have killed one German, kill another: there is nothing more joyful for us than German corpses. Don't count the versts. Count one thing alone: Germans whom you have killed ${ }^{36}$

Ehrenburg's slogans could now easily be interpreted as support for the eruption of violence. ${ }^{37}$ While the German communists who accompanied the troops frequently condemned the Soviet army's rampage, they themselves were unsure about how their countrymen should be treated. Too many people had supported and voted for Hitler for them not to carry a share of responsibility. ${ }^{38}$

The social divisions in the Red Army often inflamed clashes between commanders and their troops. As B. J. Kospoth, a British POW held captive in Pomerania and liberated by Soviet troops, remembered: '[o]fficers and soldiers of the Red Army's motorised troops seemed to be an entirely different type of men ... from their comrades in the infantry. I have known them to warn inhabitants of villages through which they have passed against the undisciplined riflemen who were coming after them. I have seen them abstain from looting and even decline drinks because they were on duty. They are the aristocrats of the Red Army, while the infantry is its disinherited proletariat, its predestined "cannon fodder" in the good old Prussian sense. Most of the excesses of which the Red Army is guilty in occupied countries are committed by its ragged, hungry, lewd infantry. 39 
It was this infantry of angry and starved men that set the tone of the occupiers' relationships with the German population. Not only did their attacks limit the possibility for friendly relations at the outset, but they also added a further set of health and social problems. First, as waves of suicides took place, often directly in anticipation of or response to the arrival of the Red Army, more corpses had to be disposed of, and failed attempts required medical attention. Theodor Plievier wrote of 'an epidemic of slashed wrists - attempts which succeeded only rarely'. ${ }^{40}$

Second, the mass rapes resulted in tens of thousands of unwanted pregnancies, and women throughout the zone turned to doctors to carry out abortions, or they simply carried them out on their own. ${ }^{41}$ The Berlin health authorities, in agreement with the SMAG, temporarily suspended the legislation which prohibited abortions (the notorious Paragraph 218), making it possible for the district health officials to sanction them, at public cost, until almost the last month of pregnancy, 'on any women who certified that she had been raped by a foreigner, usually but not always a member of the Red Army'. 42

Third, the rapes also dramatically increased the rates of venereal diseases, as hundreds of thousands of individuals contracted and passed on infections. The VD problem was to haunt the Soviet and the German health authorities for years to come, in spite of the SMAG health officers' pleading to mobilize all resources at their disposal. ${ }^{43}$ The Soviet commanders introduced a ban on fraternization, rather belatedly in the summer 1946, over a year late, and after the Americans had abandoned their ban. It sanctioned only official Soviet-German contacts, but seemed to have had little immediate effect, as many Soviet soldiers were still billeted in German communities. ${ }^{44}$ While for the Western Allies the non-fraternization policy was to prevent opportunities for pro-German propaganda to influence Allied soldiers, in the Soviet zone it was primarily a measure to contain the VD problem, and, in part, also to protect the German population. American and British observers (particularly those opposed to non-fraternization in their own zones) noted with concern that the Soviets seemed to lack any real rules against fraternization. ${ }^{45}$ The strongest message about rape only came in March 1949, when a directive by the Presidium of the Supreme Soviet provided serious punishment: a mandatory sentence of ten to fifteen years in a labour camp. ${ }^{46}$

The devastation and disorder were altogether more severe in the Soviet zone than in the rest of the country, but many of the problems mirrored those elsewhere. The change from fighting a war to organizing a peace was difficult and beset with contradictions. The Soviet military government was overtaxed, stretched by too few personnel and resources, and too many urgent demands. From 1945 to 1949, the SMAG ran the zone. Its central headquarters were based in the Berlin district of Karlshorst, and it had offices in each of the five provinces of the zone, as well as the special Berlin Kommandatura. Its structure stretched to eighteen district offices (which in 1946 were reduced to twelve, and dissolved completely in 1948), below which were the local German organizations. ${ }^{47}$

The plans had provided for far too few personnel, but in the first months of the occupation the SMAG establishment expanded rapidly: the spring 1945 directives had planned for 125 staff; the first organizational charts from July 1945 provided for 1,447 positions in thirty specialist departments; and only a year later the SMAG counted 60,000 jobs. ${ }^{48}$ Nonetheless, expanding the personnel charts was one thing, but filling the jobs was quite another. In practice, personnel shortages remained acute for a number of reasons: bureaucratic recruitment procedures, the unpopularity of service in Germany, and the fact that many officers were sent home for a variety of offences. ${ }^{49}$ The SMAG's Health Department was one of the many departments affected by these shortages. Founded by an order on 6 June 1945, it began its work on the basis of SMAG Order No. 5 from 10 July 1945. ${ }^{50}$ It was headed by Major-General A. Y. Kuznetsov and his deputy, Colonel Andrei J. Sokolov, and initially made up of around 100 members, drawn from a range of Soviet medical faculties and the Red Army sanitary service. A chart of the department from summer 1945 listed 96 members of staff. In 1946 this had grown to 110, but then shrank to just 70 in February 1947. By 1949 there were only 41 people left. ${ }^{51}$ The majority of Soviet health officers were well qualified - according to a number of envious reports by western officials, a 'highly qualified elite force' - but there were not enough of them, many did not speak German, and few had been sufficiently prepared for the turmoil and devastation in Germany. ${ }^{52}$

The Health Department's responsibilities were directly comparable to those of the other zones. It was to oversee and direct all practical public health business: organize epidemic work, create the basic structures of a sanitary infrastructure and German health service, control the personnel of the German health service and its institutions, oversee medical supply and distribution across the zone, resume the work of German medical industry (for both German requirements and Soviet reparations demands), and direct the medical departments at the universities. Unlike the British and American health offices, it was also specifically charged with studying the German health system and medical industry (and was given the archive of the military-medical Friedrich Wilhelm Academy for this purpose) so as to identify and extract useful research and products for Soviet use. 53 
Soviet health officials' work was made easier because they had already identified, in principle at least, potential German collaborators, and agreed to make use of them wherever possible - both Germans already in the zone and those still in exile. In the spring of 1945, three 'initiative groups' of German exiles accompanied the Red Army to Germany. Walter Ulbricht's group went to Berlin and helped to set up the new Magistrat and the Berlin district councils. The second group was headed by Anton Ackermann, and moved with the First Ukrainian Front into Saxony. The third group, led by Gustav Sobottka, joined the Second Belorussian Front on its move into Mecklenburg. All three assisted the Soviet occupation authorities. Their first tasks concerned the recruitment of German administrators, and the formation of local and regional authorities. In many cases, they themselves took up leading positions in these new organs. ${ }^{54}$

This collaboration of Soviet officials with German émigrés and 'trusted persons' alleviated some of the problems that distracted the other occupiers. Through KPD initiatives, over 70 German communists and 300 re-educated POWs were sent back to Germany for administrative work during June 1945, and afterwards the Soviet authorities regularly gave in to KPD requests for more cadres from the POWs in the antifascist schools. ${ }^{55}$ Of the thousands of POWs who eventually returned to the Soviet zone, many ended up working for the police force, an area in which the British authorities faced enormous recruitment problems. ${ }^{56}$ As time went on, the Soviet authorities at regional levels also increasingly relied on regional KPD party groups, especially for their 'general situation reports' and their testimonials on candidates for jobs. In the field of public health, too, Soviet officials relied on this German input to put a form of 'indirect control' into practice.

That is not to say that there were no problems. The occupiers held the absolute authority for decisions, and the Soviet officers' early appointments of mayors and local authorities could be just as random and ill-judged as those in other zones. Selections were often a result of coincidence, convenience, and ignorance. While Soviet commanders did regularly seek out those recommended by émigrés as opponents of the Third Reich, and they did frequently appoint such individuals, this strategy was not foolproof, nor were there sufficient numbers of trusted people available. Active Nazis and incompetent people regularly found their way into administrations, here just as in the other zones.

Nonetheless, the complete lack of orientation and guidance that weighed down particularly the British, was alleviated by consistent orientation points: German antifascists (above all communists and social democrats) were recognized to share important interests with the Soviet authorities, and were enlisted to carry out the most urgent tasks, without having to convince Soviet politicians that such contacts were necessary.

Even before the local administrations were set up, the Soviet authorities actively sought to pass responsibilities to the Germans. ${ }^{57}$ Following the guidelines formulated by the KPD, they tried to appoint house and street elders (Obleute). The guidelines had specified that local and municipal administrations were to rely on a network of individuals who could oversee developments on a very micro-level: in their streets, blocks, factories. The appointment of house, street, or block elders was often one of the first acts of the military commanders. ${ }^{58}$ Unlike in the western zones, these early appointments could be made without having to appease weary and watchful politicians at home.

These 'elders' or 'trusted persons' were used for a variety of basic tasks: to help organize the clearing of rubble, the compilation of lists of inhabitants and early censuses, the distribution of ration cards, and later more substantial population counts. ${ }^{59}$ Their methods were not always appreciated. In November 1945 the mayor for the city district Mitte reported that in response to the order to clear rubble, street and house trustees had been trying to enlist the population to help. 'But one street trustee', the mayor noted with concern, had done this 'in a manner in which we no longer want to act today. He simply wrote: "Those who do not come to shovel rubble won't get ration cards!" The district officials must ensure that street and house trustees put their demands to the population in more polite terms, because we do not want to employ Nazi methods! ${ }^{60}$ Such conflicts notwithstanding, the Soviet authorities initially saw these trustees as useful for the collection of information and for ensuring the population's compliance with orders. ${ }^{61}$ To people like Walter Ulbricht, they were also the backbone of a new organization — potential building blocks as well as means of control.

In Berlin this temporary system facilitated general control in the early occupation, but it was of special significance for public health operations. In order to contain the spread of infectious diseases, health officials had to locate, identify, and then treat or isolate infected persons. The new Magistrat health office instructed all doctors in the city to take part in this work. ${ }^{62}$ But the identification of infected people was fraught with problems, since so many had reasons to avoid contact with the authorities. Unregistered refugees and displaced persons tried to hide away, as did Nazi Party officials, Wehrmacht deserters, escapees from POW camps, as well as looters, criminals, orphans, and prostitutes. Confinement in quarantine camps was dreaded by all. House trustees were enlisted to help. At a Magistrat health meeting in June 
1945 it was agreed that with help from 'the street and health trustees and suitable assistants, every existing household is to be checked for suspected cases of infectious diseases. They are to be reported to the responsible doctor, who will examine them and in turn report to the district health official. ${ }^{63}$ Over the next few months, the district health officials regularly enlisted the trustees for health work. Less successfully, they were occasionally used to locate Nazi doctors and their property. 64

The trustee system was abandoned as more permanent German authorities were established. After the Western Allies moved into their sectors of Berlin in July 1945, they initially made some use of the elders already in place, but then banned the system. ${ }^{65}$ Even Ulbricht and the KPD leadership lost interest once the formation of political parties had been allowed and they could proceed with more systematic party work. The establishment of local, municipal, and regional authorities now became the prime focus. But here, too, the Soviet authorities' German contacts facilitated and sped up the construction of these more permanent organizations.

The Soviet preference to give the Germans responsibility for as much of the routine administration as possible certainly stemmed to a large degree from their personnel shortages, a problem comparable to, but more severe than, the American demobilization pressures, and which had eventually similar results. Soviet health officers complained regularly about shortages. An officer based in Brandenburg, one of the most devastated areas of the zone, complained in November 1945 that only four health officers were available for the area, and the head of the Health Department had been away on leave for most of the month. It was vital, he argued, that more staff were made available - at the very least, those going on leave had to be assigned deputies who could carry on in their absence. Soviet specialists also had to be recruited, particularly epidemiologists and venerologists. ${ }^{66}$ Lack of personnel also hampered the American and the British health operations, but the Soviet authorities were less cautious from the outset about the establishment of German administrations, and they proceeded earliest. In late June 1945, after the British and Americans had withdrawn from the territory of the Soviet zone, the SMAG released an order to create military government offices in the five provinces, to be matched by German provincial administrations. ${ }^{67}$ They were formally endorsed at the beginning of July 1945 , and received legislative powers in October $1945 .{ }^{68}$

Unlike the other occupation powers, who at the outset only established local and regional German administrations, the Soviet authorities quickly took steps to create German-staffed specialist zonal authorities. ${ }^{69}$ Soviet Order No. 17 of 27 July 1945 established a series of central administrations (Zentralverwaltungen), to function essentially like ministries and responsible for the whole zone. The Central Health Administration, the Zentralverwaltung für das Gesundheitswesen (ZVG), was one such quasi-ministry, with German émigrés and their old political contacts from before 1933 making up a significant part of the organization. ${ }^{70}$ While British officials struggled to implement some form of indirect control of German health workers, the Soviets found this easier, undoubtedly aided by the fact that Maxim Zetkin (a Soviet citizen, whom we have encountered in Chapter 4), was vice-president of the ZVG and above suspicion - a real 'intermediary'. Soviet officers sometimes seemed embarrassed about telling German doctors and health officials what to do, since, in their eyes, German medicine was so superior. ${ }^{71}$ In these conditions, the ZVG soon developed from a mere recipient of Soviet orders into a powerful institution. ${ }^{72}$ On issues not affecting the health of the Soviet troops, it was left essentially a free hand. ${ }^{73}$

The availability of German collaborators, and their practical preparations, alleviated some of the taxing problems of the early occupation period. Nonetheless, the Soviet zone was no different in that many of the projects could not be fulfilled. The conviction that it would be possible to compile complete registers of former NSDAP members (as had been anticipated in the KPD guidelines), let alone punish them consistently, proved naïve and unfeasible. For many in the Soviet zone, Nazi Party membership, and particularly an individual's degree of activity in and support of the Nazi regime, remained contested and disputed for years to come.

The cleansing of German society from Nazi personnel and ideology was to be a major part of Soviet policy in Germany, and that included the health service. Some of the earliest evidence on German medical atrocities had been collected by a Soviet committee, years before preparations began for the American-initiated Nuremberg medical trials of 1946-7. Stalin had established the National Commission on Nazi War Crimes in November 1942 to collect evidence on German atrocities through interviews with witnesses, interrogations of German prisoners, forensic investigations, and documentary research. Between 1943 and 1947, the commission prepared over 250,000 reports. Such evidence was marshalled by the Soviet authorities in their first prosecutions of war crimes of the Second World War; the particular case concerned a German massacre of psychiatric patients at Kharkov, but on the basis of these investigations other details of German medical atrocities were then also widely publicized. ${ }^{74}$ 
The Soviet authorities took early steps to intern leading Nazi officials and remove active party members from their offices and positions of responsibility. Like the other occupiers, they used questionnaires to assess individuals' involvement in Nazi activities (see Fig. 7.1). ${ }^{75}$ The medical profession was only one of the many professional groups to be denazified. As in the other zones, Soviet and German officials were aware of the extent to which doctors had been active within the NSDAP and its affiliated organizations. A ZVG memo from March 1946 estimated that at least ' 65 to 80 per cent' of the doctors in the Soviet zone had joined the NSDAP. ${ }^{76}$ Among doctors in Saxony, a Soviet report stated, 'up to 85 per cent were members of the fascist party. Undoubtedly, this fact has resulted in the widespread infestation of the organs of health with fascist elements. Cases have been observed, where individual leaders of the German health institutions have concealed their membership of the fascist party, and only after careful, many-sided study of the leading elements of the German health service were all the fascists revealed. ${ }^{, 77}$ In January 1946, Kuznetsov reported to Marshall Zhukov that even after the most ardent Nazis had been sacked from the medical faculties, the numbers of Nazis remained high. 'In Halle and Thuringia', Kuznetsov went on, no purge at all could be carried out 'because of the absence of transport'. 78

German health officials were concerned by early signs that the Soviet authorities intended to take the purge of the health service very seriously. When Georg Wundram was appointed by General Berzarin in May 1945 to organize and run the Berlin veterinary service, it initially seemed to be straightforward. 'When I asked whom I should consider,' Wundram remembered, 'the gentlemen told me the following: You can take anyone who joined or was forced to join the party after 1933, as long as they did not act as functionaries.' But just a few weeks later, on 30 June 1945, a Soviet order demanded the immediate dismissal of all former party members, and Wundram was now told that, from 'the 20 veterinary officers just recruited, I had to dismiss 12 immediately'. Wundram 'made a complaint to Councillor [Wilhelm] Pieck, and we agreed that those who had been dismissed were to be re-employed a few days later as individuals conscripted to community service'. ${ }^{79}$ But the incident seemed to signal that the Soviets' denazification intentions were not to be written off lightly. Dr Wolf, a German health official from Saxony, reported in November 1945 that his office had given the Soviet authorities a list of 'over forty people' who were 'simply indispensable'. But the Soviet officer had not been sympathetic at all —'thirty people have been crossed out, and for the remaining ten a deadline for their replacement has been given: a fortnight, at most four weeks ${ }^{,}{ }^{80} \mathrm{~A}$ few months later Kuznetsov wrote to Zhukov that 'it has been suggested, for a second time, to the heads of the sector of the province to carry out a quicker and more energetic purge in the German organs of health and to replace members of the fascist party by antifascists and democratically inclined doctors'. 81

A number of doctors, particularly in the fields of virology and vaccine research, had been under suspicion for some time. The bacteriologist Heinrich Zeiss, who had established the central bacteriological laboratory in Moscow in 1921, and worked there and at other biochemical and medical-geographical research institutes until his contract was terminated in 1930, now came into view again. He had reported details on Soviet conditions to the German embassy in Moscow throughout his time in the Soviet Union, had joined the NSDAP in 1931, and in 1933 became director of the prestigious Institute of Hygiene in Berlin. Although the NKVD's accusation that Zeiss had masterminded the bacteriological warfare against the Soviet Union could not be substantiated, it was not surprising that Zeiss was arrested in 1945. In fact, we now know that Zeiss's diverse research projects were all geared towards the German conquest of the East. ${ }^{82}$ He was tried by the Soviet authorities in 1947, and died in March 1949 in a prison hospital in Vladimir from Parkinson's disease. ${ }^{83}$ Even if some of these efforts were driven by score-settling rather than more systematic denazification criteria, from the start the Soviet authorities made determined efforts to cleanse German society.

But denazification of the health service was seriously hampered by the shortages of doctors who could take over once the Nazi doctors had been dismissed. ${ }^{84}$ Shortages of general practitioners, specialists, nurses, and health officials were particularly severe in the two central and northern provinces of the zone, Brandenburg and Mecklenburg, and were discussed on many occasions. ${ }^{85}$ During a meeting in November 1945, a German health official from Brandenburg, Dr Christians, expressed his concern about the huge personnel problem faced by his office. They were short of at least 150 doctors. He had been ordered to staff the main office with twelve doctors, but he only had two. Although he had been asking the southern provinces for months to send him doctors, they had only managed to send four. ${ }^{86}$ But problems also existed in the south of the zone. Saxony and Thuringia, while occupied by American troops, had been saturated with doctors, but this surplus quickly evaporated when the Soviets arrived. Dr Drechsler, a health official from Thuringia, noted that before November 1945300 surplus doctors had been counted in his area, but by mid-November 1945 most of them had moved westwards into the British or American zones. ${ }^{87}$ 
The combination of potentially disastrous health conditions and serious personnel shortages limited the scope of denazification in the medical profession, and compromises increasingly dominated in the new policies. As in the other zones, the initial period of quick dismissals and strict applications of procedures was followed by a reassessment, as Soviet and German authorities insisted that more flexible and viable arrangements were necessary. And ideologically, the focus on a structural transformation of German society - the weakening of the socio-economic base which had given rise to and supported Nazism, through land reform and expropriation - made it easier to be less insistent on the removal of any particular individuals. ${ }^{88}$ Far from the ambition that NSDAP members should not be allowed to remain in any positions of responsibility, in reality, just as in the other zones, former Nazi doctors became a crucial pillar of the zone's health service.

A letter from July 1946 outlined three main problems with the denazification of medicine: '1.) Unreliability of the questionnaires. 2.) Support of some Nazi doctors from official organs. 3.) Lack of replacements. ${ }^{, 89}$ Problems with the questionnaires were widely acknowledged, and plagued not just the health service. Questionnaires alone, this memorandum reiterated, could 'give no correct picture about the political past of the person concerned. It is necessary to obtain detailed information with the help of the local police authorities, but particularly through the local groups of the antifascist parties.' The second point affected the health service more specifically. Mayors and regional administrators were keen to hold onto their doctors, Nazi or not, and regularly stymied attempts to identify and remove former Nazis from their jurisdiction. The smooth running of their regions depended, to a large extent, on a functioning health service, and losing medical personnel would only hamper their work. ${ }^{90}$ The job of convincing local authorities to part with their Nazis would be easier if new candidates were available to replace them, but they were in extremely short supply. The third point was therefore the most serious. The lack of professionally and politically adequate replacements could only be overcome over a long period of time, the letter maintained, and only through detailed coordination of the regions and the assessment of cases on their individual merits. In the shorter term, compromises had to be made.

The shortages on one hand and the restrictions imposed by the denazification directives on the other were regularly voiced concerns by German health officials. As early as June 1945, Ferdinand Sauerbruch told the Berlin health officers that the personnel question had become acute. 'In future', he said, 'personnel measures need to consider above all that the medical supply of the population suffers no significant damage.' At these and subsequent meetings, there was overwhelming agreement that those doctors who had at some point been involved in the NSDAP should be allowed to continue. This was not only because, as Sauerbruch maintained, this was the 'humanly loyal' thing to do, but primarily because it was 'in the interest of public health'. A strict application of party membership as a reason to dismiss doctors, Dr Emanuel insisted, was 'regrettable', and would 'lead to a crisis, especially in the care for venereal diseases'. .91

This argument was made more vocally as conditions deteriorated. At a meeting in September 1945, a Red Cross representative complained that ' $[\mathrm{w}] \mathrm{e}$ are doing everything possible, but we have no personnel at our disposal, no nurses and no medical auxiliary personnel. We have been told that we are not allowed to employ women who have been involved in the Nazi women's organizations. Where are we supposed to get personnel from? If the ex-Nazi women cannot be used, then nothing is possible. ${ }^{92}$ The Saxony health officer said that 'he could not easily do without the assistance of former party members, not even without the active ones'. In Brandenburg, another health officer reported, 'over 90 per cent of the hospital doctors were in the [Nazi] Party. For the time being, technically irreplaceable doctors, such as surgeons, will have to stay in their positions, but also other specialist doctors and directors must still be employed in the interim, even if they were in the Nazi Party. ${ }^{93}$ Others said that there were not even enough people available for training, which was itself a long process. A month later, one health official observed that 'we are forced into the role of the Nazi protectors, just simply by having to carry out absolutely essential work'. But, he added, he and his colleagues also knew that 'generally speaking, the equation of Nazi Party member equals Nazi activist simply does not reflect reality, 94

The realization that Nazis, even active ones, were necessary for maintaining order and preventing public health disasters also struck many Soviet officials. In anticipation of the winter months, the Soviet authorities insisted that denazification in the medical sphere had to be conducted pragmatically. Even though Soviet officials generally reserved the right to make final decisions on individual cases, they were often willing to accept lenient and pragmatic adjudications. ${ }^{95}$ As Kuznetsov explained to Zhukov, 'The general purification of these posts from Nazis is taking place dependent on the selection of suitable candidates and on the necessity of preserving an uninterrupted health service for the population, given the vastly increased tendency to get sick.' One series of compromises was made, with Soviet approval, just days after hostilities ended: people like Ferdinand Sauerbruch, Erwin Gohrbandt, and Georg Wundram 
were recruited to the Soviet zone's health service, regardless of previous military and political activities. Some Germans were disconcerted that doctors with Nazi affiliations such as Sauerbruch were being appointed, and that Soviet commanders seemed so lenient with Nazis. ${ }^{96}$

Soon, more extensive compromises were being contemplated. At a meeting in September 1945, Paul Konitzer (the president of the ZVG) explained that the question of what could be done with the ex-Nazi doctors had been raised with the Soviet authorities, and everybody accepted that compromises had to be made. At the most recent negotiation, he said, '[w]e were told that we should make those doctors and other personnel work for us. We must not give them any positions of responsibility, but should make them work under supervision. At the moment we cannot proceed without them. ${ }^{97}$ Through so-called 'emergency contracts of employment', it became possible to employ former Nazis temporarily to carry out important jobs, and to allow them to continue in their clinical jobs. Fritz Leo (or Lettow), a concentration camp survivor and department head in the ZVG, explained that while 'politically implicated men and SS doctors will be excluded completely', actually, 'as far as is absolutely necessary and tolerable, active fascists could perhaps still be employed for another three to six months'. And, he went on, 'small-fry and nominal Nazis (Mitläufer) will be continued to be treated accommodatingly. A similar procedure will be instituted for hospitals and other institutions. ${ }^{98}$

Just as in the other zones denazification was to focus primarily on the health administrative and hospital positions, and was to be applied less strictly among the general practitioners; just as in the other zones, this emphasis was hampered by the fact that health officers' jobs were not popular. Professor Walter, from the Mecklenburg health office explained: 'What can we offer our officers of health? At the beginning we could not even pay their wages. Now they get the salary of a schoolteacher. We have taken them away from their practices, we cannot give them cars, and we don't have food for them either. A man is much better off in his private practice than as a health officer. Currently I have no other doctors and have to work with 90 per cent Nazis. I consider it unlikely that we will get new recruits in the near future.' Dr Wolf pointed out that 'general practitioners - especially our disreputable Nazi doctors—earn 10,000 marks a week'. 99

It was not just health officers' jobs that were unpopular. Epidemic work, the most urgent of all, was universally loathed by doctors, especially where it required working in refugee camps and quarantine stations. As a result, the German health authorities devised a system of emergency conscription. They extended the emergency measures that had been in operation during the war years, with the crucial difference that the doctors called up were specifically those who had been members of the NSDAP. ${ }^{100}$ At a meeting in November 1945, ZVG officials explained they had agreed with the Soviet authorities that although former members of the NSDAP were generally not to be employed, '[i]ndispensable qualified personnel such as doctors, technicians, mathematicians, statisticians, technical or administrative specialists can be conscripted from the ranks of former NSDAP members, if they have not been active Nazis and if their employment is necessary for reconstruction, for the prevention of dangers or for the overcoming of crises. This is a form of work conscription. ${ }^{101}$ Soon, even active Nazis were included in this arrangement. In December 1945, a directive stated that ' $[\mathrm{w}] \mathrm{e}$ do not have enough doctors for the struggle against epidemics and the treatment of refugees', and the 'situation is deteriorating as more and more refugees arrive. In addition to the measures already ordered, the following is decreed: All doctors, if they have been members of the Nazi party or one of its affiliated organizations, who apply to district health offices for employment or permission to practice, are henceforth obliged to work in the prevention of epidemics and treatment of refugees. 102

This conscription was widely practised. Since the ratio of doctors to patients continued to be much better in the south of the zone, former Nazi doctors from Saxony and Thuringia in particular were ordered to participate in urgent epidemic operations in the most devastated areas in the north of the zone. As early as September 1945, a health official from Saxony reported that in his area, Nazis had been 'divided into three groups. The first group has to be dropped completely. The second will be used in special operations - a kind of penal appointment — and will be paid wages. The third group will be left to run their practices, but with some limitations and without the [full] responsibilities.' ${ }^{103}$ A Soviet report on the health situation in Brandenburg observed that in November 1945, thirty-five doctors had been received from Thuringia, and most were ordered to carry out epidemic work. ${ }^{104}$ Numerous individual cases also document this development. In December 1945, the ZVG sent a Dr Rauschning to the Brandenburg health office. He 'was forbidden to practise medicine by the American Military Forces because of his membership in the NSDAP', they explained, but here he was 'suitable for employment in the epidemic service'. ${ }^{105}$ In the same week, a Dr Amschler, who had also been a member of the NSDAP, was sent to Brandenburg so that he could be 'put to work in the interest of the public good', and his 'special knowledge and ability' be taken into account. ${ }^{106}$ 
Through these conscriptions, two problems were solved at the same time: the most devastated areas received muchneeded medical personnel from those with a surplus (see Fig. 7.2), and politically implicated doctors were somewhat punished by having to move to new areas and carry out difficult and dangerous work. Some ZVG people also gave a more strategic interpretation: sending Nazi doctors to new areas, where they would generally not know anybody, would help to break up 'anti-democratic cliques' ${ }^{107}$ It was perhaps unavoidable that Nazis would have to be tolerated in public health employment, one memo agreed, but it could at least be arranged that 'those reactionary elements who form a tightly woven and suffocating belt around our reform attempts' were removed from their areas, and their networks severed. ${ }^{108}$

This policy had some unintended consequences. Health officials in the areas most in need of medical personnel complained that they were only ever sent Nazi doctors, and never any politically useful individuals, which made their own denazification attempts utterly futile. Hermann Redetzky, in charge of the Mecklenburg health office, wrote that ' $[\mathrm{u}] \mathrm{p}$ to now, almost all the doctors who have been sent to Land Mecklenburg-Vorpommern to work in the epidemic service or the care of resettled persons have been old party members (memberships from 1931 to 1933). As grateful as we are about the support given in these allocations of doctors, I would like to register considerable concern about that fact that only such heavily implicated Nazi doctors are being sent to us. The already difficult issue of political cleansing and the assistance of Nazi doctors is thus made infinitely more problematic. Of course, I have no complaints about the practical work done by these doctors, but I believe that it must be possible to make a more balanced selection. ${ }^{109}$ At a meeting in November, Dr Christians reiterated that he did 'not want the province of Brandenburg to become a high density province, or that the Nazis from SS-Obergruppenführer to SS-Untergruppenführer all end up in the province of Brandenburg, of all places. From a hundred doctors, I would like to get at least ten antifascists. 110

These pleas had little effect. Even more problematic was that doctors often resisted the conscription orders, or fled on the way to their new placements. Dr Christians noted that 'doctors come very unwillingly to the province of Brandenburg, and when they see the delightful scene that awaits them, they don't even get out of the train'. ${ }^{111}$ In November 1945, a note from the Thuringia health office stated that of 106 ex-Nazi doctors sent to Brandenburg and Mecklenburg, only 80 had reached their destination. ${ }^{112}$ The Saxony health office reported that from their initial surplus of over 300 doctors, half had meanwhile fled to the western zones, and the other half had simply refused to be conscripted. ${ }^{113}$ Mayors and other district officials often supported the doctors' refusal to move, and the ZVG's attempts to take 'strictest measures', or 'to lock up ruthlessly all those who refuse[d]', were greeted with scorn. ${ }^{114}$

In spite of these problems, the conscription of former Nazi doctors into the health service was widely seen as an effective measure. While conscription into the epidemic service had been designed as a stopgap measure, and even a form of punishment, in practice, much to the disgust of left-wing health officers, it was often a means for the permanent rehabilitation of Nazi doctors. In December 1946 the communist Carl Coutelle noted with concern that the epidemic urgency had passed, but that many of those sent to new areas had in the meantime opened new private practices. Nobody bothered them anymore since they had apparently done their duty, and, since the health authorities in their new areas often did not know about their backgrounds, they rarely had to face any further denazification. ${ }^{115}$

While the conscription itself was based on necessity, it also contained the idea both of a neutralization of Nazi elements in the public health service, and the possibility of atonement or probation through such work. Occasionally it was spelled out that work in the epidemic operations could enable Nazi doctors to make up for their past. One notice proclaimed that by relocating to areas where they were most needed, 'every doctor does his bit to overcome the heavy burden of guilt which unworthy doctors have incurred in their treatment of other peoples and their own countrymen in the concentration camps'. ${ }^{116}$ Sauerbruch, who himself was not very keen on an appointment to the Berlin Magistrat, was offered a kind of atonement: 'especially because you have loaded on yourself a certain share of the blame,' he was told, 'you must now do everything to help the millions of Berlin inhabitants by building up an ordered health service and thus to protect them from the serious damage of epidemics. This is an honourable task. ${ }^{, 117}$

Although health conditions gradually improved — by late 1947 most water and sewage installations had been repaired and the major infectious disease rates lowered - German and Soviet commentators were forced to conclude that the denazification of the medical profession had largely failed. As Kuznetsov noted in February 1946, not only were communists and social democrats still a minority in the German health service, but the removal of Nazis had so far been unsuccessful. Among the local and regional health departments, he wrote, there were at least 25-30 per cent former Nazis, and the 'chief doctors at the hospitals, who play a considerable role in the German populations' health provision, are the group which is most infested by former Nazis. Amongst 417 chief doctors of the major hospitals ... there are over 50 per cent Nazis. 118 


\section{Confrontations}

Confrontations between German and Soviet officials took place over a range of issues. Conflict stemmed particularly from German dismay about regular reminders that Soviet interests, rather than German welfare, were of primary importance. One of the most contentious problems was that of venereal diseases, at all times a major concern of the Soviet authorities. Soviet reports contained lengthy discussions of this topic, and expressed great alarm about high infection rates among their troops and the population at large. The German authorities were blamed when a series of measures and Soviet orders did not seem to have had much effect. A Soviet health officer based in Saxony reported that 'the VD infection rates among the military personnel in the area, which remained high during October, have also not improved in November. The German authorities have failed to open venereal departments in Dresden and Leipzig. ${ }^{, 19}$ Some months later, Kuznetsov complained to Zhukov that, despite his department's best efforts, VD rates were still very high, mainly because the German health authorities had not done enough to reduce them. The high VD rates, he maintained, could be 'explained not only by the current social and economic circumstances of Germany, but they are also the result of the unsatisfactory work of the German organs of health. Despite an increase in the number of medical institutions which treat venereal diseases, the German organs have still not taken satisfactory measures in response to the commander-in-chief's order of 7 August 1945 to come to grips with venereal diseases. 120

These complaints about inadequate German efforts to some extent reflected Soviet health officers' attempts to avoid responsibility for failures and administrative responsibilities. But they also stemmed from the realization that German doctors did not always agree that the VD problem really was the most pressing of all the health issues. In November 1945, Franz Redeker reminded a Magistrat health meeting yet again that 'the occupying powers were particularly sensitive with regard to venereal diseases'. The meeting knew what this entailed - having to concentrate all efforts into VD control when other problems, tuberculosis for example, were deemed to be more urgent. ${ }^{121}$ These tensions were exacerbated because, in contrast to the Western Allies, the Soviets had hardly any penicillin at their disposal to make VD treatment more popular. Treatment was dependent on traditional and unpopular methods without rapid results, such as the use of Salvarsan, which had long and complex treatment courses and side effects. ${ }^{122}$ Penicillin, which made the treatment of gonorrhoea and syphilis so much faster and painless in the other zones, was only available in very small quantities in the Soviet zone, and never for the treatment of non-venereal diseases, much to the German health officials' dismay. ${ }^{123}$ In February 1946, a SMAG report complained of shortages and called for increased production of penicillin at the plant in Adlershof, and the urgent supply of other drugs through the Soviet zone's trade with the western zones. ${ }^{124}$ But the ZVG complained about severe shortages of penicillin as late as January 1949. ${ }^{125}$ Throughout the post-war years, at joint meetings of health officials from the four Berlin sectors, those from the eastern city districts heard how their western colleagues had been given drugs which they themselves lacked. ${ }^{126}$

Perhaps the greatest source of confrontations between German and Soviet officials, and between different Soviet interests, regarded the policy of extracting reparations from industrial installations, from goods and raw materialsincluding both the organized waves of dismantling industries, railway tracks, and harbour installations, and the Soviet soldiers' spontaneous hunts for trophies (including raw material, cars, food, money). Initially, the situation was particularly extreme in Berlin, where much of the industrial centre was to be removed. Dismantling squads rushed to work, because the imminent arrival of the other Allies in the western sectors meant they would soon have to give up those parts. As Theodor Plievier described, '[t]here had hardly been time to clear up the corpses of the war casualties and suicides which were lying everywhere in the grounds. Machines, furniture, work benches and cupboards, window and door frames, floors and window sills, water pipes and drains, electricity cables, the "whole works" as the lieutenant called it, everything had to be dismantled. 127 This practice seemed to confirm the German stereotype of the barbarian, destructive, and stupid Russian enemy. The population saw little distinction between dismantling and plain demolition. Sticking to the timetable and loading the necessary weights appeared more important than the condition of the goods obtained, and much was broken.

The Soviet Health Department was directly caught between the priority to collect German research, drugs, and goods on the one hand, and stabilizing the public health situation on the other. The resulting tension was a recurrent subject in the health reports submitted by Kuznetsov and his staff. A December 1945 report on the public health conditions in Saxony illustrated at length that, here, in 'the richest province in the whole of the Soviet occupation zone of Germany', all important industries could be found. The area was 'the base for the provision with goods, both for the maintenance of the occupation forces and also for the delivery of goods to the Soviet Union by way of reparations'. 128

Kuznetsov regularly compiled lists of what had been dismantled and studied under his department's supervision, and listed the wagonloads of medical equipment and drugs which had already been sent back to the Soviet Union. ${ }^{129}$ In 
February 1946, he wrote to Zhukov that under the newly designed production plan for German medical industries 'it has been envisaged that medicines and instruments worth approx. 30 Million marks should be produced for delivery to the [Soviet] Union and for covering the needs of the occupation forces'. The SMAG Health Department had worked out a plan of reparations, Kuznetsov went on: particularly those items which were 'in greatest deficit in the USSRascorbic acid, bromine and x-ray tubes, etc.' were to be delivered to the Soviet Union. ${ }^{130}$ Medical institutes and university clinics were also to be dismantled. 'In connection with the excessive surplus of medical faculties in the Soviet Zone', Kuznetsov said, 'the decision was taken not to continue the medical faculty in Rostock, and instead to send its equipment to the Soviet Union so as to allow for the re-establishment of the Stalingrad medical institute. Following a government decision, a group of professors from the Stalingrad medical institute are currently visiting the zone. They are engaged in the selection of equipment for their institute. 131

The harsh reality of reparations resulted in German protests, but this was not simply a conflict between Germans and Russians. The reparation teams were also resented by many military government officials for disrupting the smooth running of the zone, and there were considerable tensions within the Soviet military and between the authorities responsible for extracting reparations and those responsible for relations with the Germans. ${ }^{132}$ The ruthless policy of removing as much material as possible, and as quickly as possible, it was regularly argued, would cause economic chaos and political uprisings, and undermine the Soviet ability to administer the zone, not to mention their reputation. Kuznetsov's Health Department was caught between conflicting Soviet agendas. While obeying reparations policy, health officers argued that, given the prevalent concerns about epidemics, German medical industry would have to produce significant amounts of vaccines and drugs for German consumption, or else imports were going to be necessary. This seems to have had some success, even before Soviet economic policy was altered more dramatically in 1947. A newspaper article in October 1945 reported that because of the dire need for vaccines, a series of medical factories were being restarted in the zone. Zhukov also ordered that German health offices were to be given vaccines from the Red Army stores, and one store had already handed over 3,000 litres of typhus vaccine to the Berlin authorities. 133

Many Germans justified their hatred of Soviet rule by pointing to the evident randomness of their appropriations and their lack of interest in the plight of the German population. Doctors and health officers, in particular, complained about how Soviet commanders had taken their cars, petrol, or clinical equipment. How could they, as agreed, build a new medical institute, one letter from the ZVG stated, if the commander in Saxony had confiscated their 3,000 tons of cement? Their building officials had told them that they could do nothing until the cement was released. This case was only resolved when Maxim Zetkin met the Soviet authorities in person and obtained the release of the building materials. ${ }^{134}$ At a meeting of German health officers in November 1945, Professor Walter from the Mecklenburg health office reported that it was crucial to the fight against tuberculosis that the population was screened by X-ray examinations, but '[i]n Mecklenburg, the majority of sanatoria have been seized by the Red Army, and we are temporarily defenceless against that'. ${ }^{135}$ Among individual doctors, the confiscation of their cars and petrol were fiercely resented. One example of many is Dr Bendixen's complaint that his car had been taken, even though he presented the Soviet officer with his special licence. After much pleading, it had eventually been returned, but with differently sized tyres so that he could still not use it. 136

Complaints from the social democrat and communist health officials stemmed particularly from their disappointment with Soviet policy. Their own political work was made so much harder, they argued, and their credibility reduced, because the Soviet authorities not only did not seem interested in building socialism in Germany, but actually hindered their own efforts in this respect. Max Klesse, a social democrat who worked in the ZVG, argued that '[a]t least we Marxists know so well that the necessary re-education of the German people is no purely ideological or pedagogical matter, but depends on us antifascists having to win the confidence of the masses through stable prices, wages, and work conditions. If the German people fell for Hitler, it was not least because with the help of rearmament, control of money and capital markets he managed to take care of the lives of the little man.' The supply questions would have to be solved urgently, Klesse argued, as so many communists and socialists had taken up positions in the administrations, public opinion would blame any failures on the Left. It was especially counterproductive, 'if the population sees how entire factories such as the local DIWAG are being "relocated", and patients will start to die in the foreseeable future because they have no insulin and liver medications'. 137

A few weeks later, Klesse again vented his anger over the nature of Soviet rule. Soviet commanders abused their power, he wrote, and their 'objective incompetence' and 'lack of any sense of responsibility', combined with the fact that so many in the Red Army were stealing or simply taking what they wanted, were very counterproductive. He was fed up with the indifference shown by many of the Soviet administrators, he declared, as well as their 'stinking 
laziness, complacency, and rudeness, especially by the lowest ranks of officials and translators and other liaison personnel of the Red Army, who often treat Germans like dirt or simply ignore them altogether'. As an urgent measure, 'the dishonest, the incompetent, the lazy, the irresponsible, and the other kinds of parasites' must be removed from service in Germany. But 'one of the gravest aspects' of the current situation, in Klesse's view, was 'the very scant consideration of the Soviet Union for the positions of the Left in Germany'. Overall, 'the destruction of the German industrial basis weakens the proletariat and the entire Left, the expulsion of the eastern Germans by the Poles threatens the food supply, and the removal of German locomotives and railways puts at risk any potential imports'. All this would prevent any real change in German society. 'The result must be to stir up nationalism again,' he wrote, 'because actual existence determines consciousness: hunger, cold, disease, and epidemics will not be blamed by the masses on Hitler, but shoved onto the Soviets and the German Left, unless some significant changes will take place shortly. ${ }^{138}$

These disputes were undoubtedly intense and bitter: there were regular Soviet complaints about the German authorities' lack of drive and initiative, and the counteracting German ideas of betterment of the indigenous population. There was little room for reconciling these positions. In February 1946, Kuznetsov grumbled that the 'newly created apparatus of the central German health administration still needs systematic help and leadership because of its lack of suitable administrative experience. This help is given to it by the Health Department of the Soviet Military Administration. ${ }^{139}$ Similarly, Soviet officials in the regional military government offices sometimes insisted on doing even the most trivial tasks themselves. ${ }^{140}$ In July 1949, one leading SMAG officer declared that the German central administrations had only produced a lot of paper, and left 90 per cent of the work to the SMAG. 141

But in contrast to the British zone, and more quickly than in the American, the slogan of 'indirect rule' characterized the Soviet control of the German administrations throughout the occupation years - at least in aspiration, if not quite in reality. Responsibility for public health work rested on the German authorities from the start, and Soviet-German confrontations were not accompanied by a Soviet rejection of German legitimacy or ability to do this work. Rather, these tensions have to be understood as attempts by the Soviet officers to make their own jobs more important. Soviet health work across the zone consisted primarily in the distribution of orders (which they had been given by the central SMAG Health Department in Berlin) to the German officers in their region, and in the initiation of surveys and inventories. ${ }^{142}$ Soviet officers could then do little more than 'suggest' to the German authorities that certain things should be done. As one report stated, '[i]t has been suggested to the German self-administration of the POW camp ... to carry out a two-week-long quarantine and to strengthen the sanitary-prophylactic work in the DP camps'. ${ }^{143}$ They frequently complained that the German health departments nominally under their control often bypassed them entirely, which not only contradicted the logic of the occupation, but made them seem less important than their colleagues in other parts of the occupation machinery. 144

The German medical officers, in turn, resented any interference and often simply shrugged off or ignored their occupiers' criticisms, whether about their failures in the control of VD or on other questions. Soviet complaints about the inadequacy of disease rates were typically answered by the argument that current conditions made German doctors' work impossible. At one meeting in Berlin in October 1945, Soviet health officers complained that typhus patients were taken to hospitals only days or even weeks after their infection, undermining any quarantine efforts. German doctors responded that there was nothing they could do: the refugee influxes were not being regulated by the occupiers, and resulted in huge deficiencies that hampered their work. They were overworked already, and the Soviets made demands that were impossible to fulfil. Above all, their epidemic work was limited by great shortages of food and drugs. 'If one can only give out advice instead of food and vitamins', Dr Emanuel noted, 'this merely arouses the population's distrust'. ${ }^{145}$ On another occasion, German health officers argued that as hard as they tried, they were slowed by the fact that 'organizational issues had not been solved (such as the refusal to grant petrol, the steeling of our cars and bicycles, and so on)'. 'Incidentally', they noted, 'the local Russian commanders were only rarely sticking to the orders they had received from the Soviet administration. 146

Despite these quarrels, the fact that the weight of administration rested on the German officials was beyond doubt. The data and findings from the German health officials were regularly incorporated into Soviet reports without amendment, often even without identification. Sometimes even data about Soviet troops were taken from the German authorities. 'Why do you use data about Soviet military personnel VD infection rates from the German health authorities?', one commander queried - not unreasonably, since Soviet personnel were not allowed to be treated by German doctors. ${ }^{147}$ On questions which did not directly impact on Soviet troops, the German health authorities were generally left in charge of their own work and designed their own policies. Even in disputes between different German authorities the Soviet authorities rarely got involved. The Soviet personnel shortages had dictated that German authorities be used 
consistently and from the start, and this was reinforced by the availability of reliable Germans who could carry out this work.

The Soviet authorities relied heavily on preparations by German émigrés, and used them to supplement their own directives. Although they gave no guarantees that the émigrés' instructions were going to be considered and acted upon, the usefulness of these preparations struck many Soviet commanders in charge of new territories, and many of the recommendations were implemented. It was precisely this level of intermediaries between the occupiers and the occupied (both the émigré communists themselves, and the trusted persons appointed by them) that was missing from the British and American preparations. As a result, the Soviet authorities came equipped with some instructions, even though they had not prepared themselves in any detail for the handling of many specific occupation tasks. Neither emergency public health nor the longer-term reorganization of the German health service featured in their preparations, but they could nonetheless begin public health tasks quickly by drawing upon the German communists' and AngloAmerican authorities' insights.

However, most of the potential benefits of the SMAG's early and consistent policy to operate public health work through the German health officers were cancelled out by the significantly worse material starting conditions, which were exacerbated by the Soviet dismantling programme, the behaviour of Soviet troops. and the policy to let their troops live off the income, produce, and production of the zone. By the autumn of 1947, Andrei Zhdanov and his supporters in SMAG, who favoured an approach which prioritized Soviet political over economic intervention in Germany, seemed to be winning the argument ${ }^{148}$ — but by that time it was too late. The announcement (in June 1947) and arrival (from mid-1948) of Marshall aid to the western zones, but not to the Soviet zone, cemented and widened the material and political divisions between the East and the West of Germany.

\section{Footnotes}

1 For an overview, see Mary Fulbrook, History of Germany, 1918-2000 (1991; Oxford, 2002).

2 Amy Knight, Beria: Stalin's First Lieutenant (Princeton, 1995), 143. Peter Davies, Divided Loyalties: East German Writers and the Politics of German Division, 1945-1953 (London, 2000), 20. Martin McCauley, Routledge Who's Who in Russia since 1900 (London, 1997), 225.

3 Naimark, The Russians in Germany: A History of the Soviet Zone of Occupation, 1945-1949 (1995; Cambridge, Mass., 1997), 167, 26. Rainer Karlsch, Allein bezahlt? Die Reparationsleistungen der SBZ/DDR, 1945-1953 (Berlin, 1993). Vladimir Rudolph, 'The Agencies of Control: Their Organisation and Policies', in Robert Slusser (ed.), Soviet Economic Policy in Postwar Germany: A Collection of Papers by Former Soviet Officials (New York, 1953), 18-86.

4 Peter Knirsch, Eugen Varga (Berlin, 1961), 9. On the reparations debates at Potsdam, see Melvyn Leffler, A Preponderance of Power: National Security, the Truman Administration and the Cold War (Stanford, 1992), 67. Also see J. E. Farquharson, 'Anglo-American Policy on German Reparations from Yalta to Potsdam', English Historical Review, 112/448 (1997), 904-26. On Soviet reparations policy, see Karlsch, Allein bezahlt?, 47, 60.

5 Naimark, The Russians in Germany, 319.

6 Naimark, The Russians in Germany, 318-21. Jeanette Michelmann, Aktivisten der ersten Stunde: Die Antifa in der sowjetischen Besatzungszone (Cologne, 2002), 58-9. Peter Strunk, 'Die Sowjetische Militäradministration in Deutschland (SMAD) und ihr politischer Kontrollapparat', in Hans Lemberg and Karl Delhaes (eds.), Sowjetisches Modell und nationale Prägung: Kontinuität und Wandel in Osteuroa nach dem zweiten Weltkrieg (Marburg, 1991), 172-3.

7 Aleksej Filitov, 'Sowjetische Deutschlandplanungen im Krieg 1941-1945', in Andreas Hilger, Mike Schmeitzner, and Clemens Vollnhals (eds.), Sowjetisierung oder Neutralität? Optionen sowjetischer Besatzungspolitik in Deutschland und Österreich, 1945-1955 (Göttingen, 2006), 25-40, at 25 .

8 See Molotov's telegram to Ivan Maisky, Soviet ambassador in London, dated 21 Nov. 1941, repr. in Jochen Laufer and Georgii Kynin (eds.), Die UdSSR und die deutsche Frage 1941-1948: Dokumente aus dem Archiv für Außenpolitik der Russischen Föderation, i (Berlin, 2004), 11-12. Also see Filitov, 'Sowjetische Deutschlandplanungen im Krieg'.

9 Filitov, 'Sowjetische Deutschlandplanungen im Krieg'. Laufer and Kynin (eds.), Die UdSSR und die deutsche Frage. Michelmann, Aktivisten.

10 Scherstjanoi in Wolfgang Benz (ed.), Deutschland unter alliierter Beatzung, 1945-1949/1955 (Berlin, 1999), 76. See also Naimark, The Russians in Germany, 9 ff. 
11 Sergei Iwanowitsch Tjulpanow, 'Die Rolle der SMAD bei der Demokratisierung Deutschlands', Zeitschrift für Geschichtswissenschaft, 15 (1967), 240-52, at 243. Jan Foitzik, Sowjetische Militäradministration in Deutschland (SMAD), 1945-1949: Struktur und Funktion (Berlin, 1999), 44.

12 Zhukov, quoted in Foitzik, Sowjetische Militäradministration, 44.

13 Foitzik, Sowjetische Militäradministration, 75-6 and 'Kurzbiographien', 476, 481.

14 Foitzik, Sowjetische Militäradministration, 76.

15 FRUS, vol. iii. 1945 (1968), 443. Ralf Possekel, 'Sowjetische Speziallager in Deutschland', in Sergei Mironenko et al. (eds.), Sowjetische Speziallager in Deutschland 1945 bis 1950 (Berlin, 1998), ii. 54. Michelmann, Aktivisten.

16 Jan Foitzik, 'Organisation der sowjetischen Besatzung in Deutschland und Auswirkungen von kompetenzieller Diffusion auf die Rekonstruktion der Besatzungspolitik’, in Hilger, Schmeitzner, and Vollnhals (eds.), Sowjetisierung oder Neutralität?, 97-116, at 106.

17 Naimark, The Russians in Germany, 10, 41. Alexander Fischer, Sowjetische Deutschlandpolitik im Zweiten Weltkrieg 1941-1945 (Stuttgart, 1975), 119 ff.

18 'Richtlinien für die Arbeit der deutschen Antifaschisten in dem von der Sowjet Armee besetzten deutschen Gebieten', 5 Apr. 1945 , KPD, Dokument 31 in Gerhard Keiderling (ed.), 'Gruppe Ulbricht' in Berlin, April bis Jus 1945: Von den Vorbereitungen im Sommer 1944 bis zur Wiedergründung der KPD im Juni 1945 (Berlin, 1993), 260-5.

19 'Richtlinien für die Arbeit der deutschen Antifaschisten', 265.

20 'Richtlinien für die Arbeit der deutschen Antifaschisten', 262.

21 Sergei Khrushchev (ed.), Memoirs of Nikita Khrushchev, ii. Reformer, 1946-1964, trans. George Shriver (University Park, 2006), 4634.

22 Bodo Scheurig, Freies Deutschland: Das Nationalkomitee und der Bund Deutscher Offiziere in der Sowjetuniuon, 1943-1945 (Cologne, 1984). Gerd R. Ueberschär (ed.), Das Nationalkomitee Freies Deutschland und der Bund Deutscher Offiziere (Frankfurt am Main, 1995). Protocol of the inaugural meeting in Moscow in Nationalkomitee Freies Deutschland, Sitz Mexico, Deutsche, wohin?: Protokoll der Gruendungsversammlung des National-Komitees Freies Deutschland und des Deutschen Offiziersbundes (Mexico, 1944).

23 Foitzik, Sowjetische Militäradministration, 46. Also see Wilhelm Pieck speech in KPD party school, 9 Jan. 1945, in Keiderling, 'Gruppe Ulbricht', 139-56.

24 Sergei Iwanowitsch Tjulpanow, Deutschland nach dem Kriege: Erinnerungen eines Offiziers der Sowjetarmee, ed. Stefan Doernberg (West Berlin, 1987), 58. Foitzik, Sowjetische Militäradministration, 45.

25 Jan Foitzik, 'Sowjetische Militäradministration in Deutschland', in Broszat and Weber (eds.), SBZ-Handbuch: Staatliche Verwaltungen, Parteien, gesellschaftliche Organisationen und ihre Führungeskräfte in der Sowjetischen Besatzungszone Deutschlands, $1945-1949$ (Munich, 1993), 7-71, at 12.

26 Keiderling, 'Gruppe Ulbricht', 100. Foitzik, Sowjetische Militäradministration, 47.

27 Foitzik, Sowjetische Militäradministration, 81. For a literary account of the work done by individuals who returned with Red Army troops, see Theodor Plievier, Berlin (Munich1954; 1st Eng. edn. London, 1956).

28 Plievier, Berlin (English edn.), 9. Dresden was almost completely destroyed by bombing raids that took place on the night of 13-14 Feb. 1945 by 800 aircraft of an Anglo-American force. The city continued to be bombarded in raids until 17 Apr. 1945. See Frederick Taylor, Dresden: Tuesday, February 13, 1945 (London, 2004).

29 From the many reports on health condition in Berlin, see e.g. LAB, B Rep. 012/902-27, Worm (Reviervorsteher, Polizeipräsident in Berlin, Polizeirevier 2) to Polizeigruppe Mitte, 'Übertragbare Krankheiten', 7 June 1945. LAB, C Rep. 118-272, Dr Schulz (Bezirksrat, Stadt-Bezirksamt Pankow) to Polizei-Inspektion, Berlin Pankow, 'Bericht über den Gesundheitszustand der Pankower Bürger', 30 Aug. 1945. LAB, C Rep. 907/03-64, Hanns Renntmeister, 'Berlin im Mai-Juni 1945' [undated] LAB, C Rep. 907/03-110, Fritz Kunze, 'Aus einem Erinnerungsbericht von Fritz Kunze, Mitglied der KPD, über die Arbeit der Antifaschisten in Kaulsdorf seit dem 23.April 1945' [undated]. LAB, C Rep. 907/03-111, Dr Hans Kupke, 'Antworten auf den Frage-Spiegel—Befreiung und Beginn der antifaschistischdemokratischen Umwälzung', [undated]. TNA, FO 1012/134, report on public health in Berlin, 10 July 1945. TNA, FO 1050/10, Chief (IA\&C Division, Bünde) to Chief of Staff, Public Health Report, 28 Sept. 1945.

30 LAB, B Rep. 012/902-28, 'Bericht des LGA II 1', 20 Dec. 1945. 
31 LAB, B Rep. 012/902-5, ‘Berichte der Leiter der Bezirksgesundheitsämter über den Gesundheitszustand usw. in den einzelnen Bezirken’, 14 June 1945.

32 The rapes of German civilians by soldiers of the Red Army tend to be discussed in isolation, but they were far from unique. On wartime rapes and post-war consequences in Hungary, see James Mark, 'Remembering Rape: Divided Social Memory and the Red Army in Hungary, 1944-1945', Past and Present, 188 (2005), 133-6110.1093/pastj/gti020 [CrossRef].

33 Helke Sander and Barbara Johr (eds.), Befreier und Befreite: Krieg, Vergewaltigungen, Kinder (Munich, 1992), 54. Atina Grossmann, Reforming Sex: The German Movement for Birth Control and Abortion Reform, 1920-1950 (Oxford, 1995), 193.

34 Repr. in Possekel, 'Sowjetische Speziallager in Deutschland', 51-2. Also see Michelmann, Aktivisten, 63. Naimark, The Russians in Germany, 91-180.

35 Ilya Ehrenburg, 'Remember' (Aug. 1944), in Ilya Ehrenburg, We Come as Judges (London, 1945).

36 Ilya Ehrenburg, 'V Germanii', Krasnaja zvezda, 22 Feb. 1945, extract in Julian L.Laychuk, Ilya Ehrenburg: An Idealist in an Age of Realism (Bern, 1991), 201-2. Ilya Ehrenburg, The War: 1941-1945 (Cleveland, 1967). Ilya Ehrenburg, 'Rats Shed Their Tiger Skins', 24 Feb. 1945, in What We Saw in Germany: With the Red Army to Berlin, by Thirteen Leading Soviet War Correspondents (London1945). Ehrenburg, We Come as Judges.

37 This point is also made in G. A. Tokaev, Comrade X (London, 1956), 290. Tokaev was one of Zhukov's scientific advisers. Many thanks to David Edgerton for telling me about this book.

38 But I am sceptical of Herf's claim that the émigrés' bitterness towards the German population was 'the justification for imposing a postwar dictatorship on an untrustworthy and dishonoured people'. Jeffry Herf, Divided Memory: The Past in the Two Germanies (Cambridge, Mass., 1997), $24 \mathrm{ff}$. Instead, from the beginning they emphasized the importance of having to work with and truly convert the German population. Nor was the Soviet occupation zone (or later GDR) understood by them as a dictatorship.

39 B. Kospoth, Red Wins: An Account of the Author's Experiences in North-Eastern Germany After Its Occupation by the Russian Army in 1945 (London, 1946), 115-16.

40 Plievier, Berlin, 203. On suicides, see e.g. LAB, C Rep. 907/03-133, Eduard Mellenthin, 'Zur Situation nach der Befreiung', 18 Mar. 1965.

41 LAB, B Rep. 012/902-5, 'Versammlung der Amtsärzte am 26.Juli 1945 im Hauptgesundheitsamt-Tagesordnung', 26 July 1945 ; 'Bericht über die Dienstbesprechung der Amtsärzte am Donnerstag, dem 6. September 1945'; 'Besprechung der Amtsärzte am Donnerstag, den 25. April 1946'. LAB, C Rep. 131/03-2, Bezirksamt Berlin-Mitte, Gesundheitsamt to Herrn Bürgermeister Weiß, 'Tätigkeitsbericht', 19 Feb. 1946.

42 Grossmann, Reforming Sex, 193-4. Atina Grossmann, 'A Question of Silence: The Rape of German Women by Occupation Soldiers', October (Apr. 1995), 43-65. Atina Grossmann, 'The Debate That Will Not End: The Politics of Abortion in Germany from Weimar to National Socialism and the Postwar Period', in Manfred Berg and Geoffrey Cocks (eds.), Medicine and Modernity: Public Health and Medical Care in Nineteenth- and Twentieth-Century Germany (Cambridge, 1995). Annette F. Timm, The Politics of Fertility in Twentieth-Century Berlin (New York, 2010).

43 BAB, Z47F, 7317/56/21, Sokolov (Deputy Head of the SMAG Health Department) to Koslenkov (Commander of health in the Province of Saxony), 26 Dec. 1945.

44 Foitzik, 'Sowjetische Militäradministration', 13. Only towards the end of 1946 were occupation troops separated from German civilians.

45 Lucius Clay to Henry Stimson, 18 Aug. 1945, repr. in Jean Edward Smith (ed.), The Papers of General Lucius D.Clay-Germany, 1945-1949, i (Bloomington, Ind., 1974), 59. Also see Naimark, The Russians in Germany, 92.

46 Naimark, The Russians in Germany, 96.

47 Jan Foitzik, 'Die Sowjetische Militäradministration in Deutschland', in Jan Foitzik (ed.), Inventar der Befehle des Obersten Chefs der Sowjetischen Militäradministration in Deutschland (SMAD), 1945-1949 (Munich, 1995).

48 Foitzik, 'Organisation der sowjetischen Besatzung in Deutschland', 106.

49 Naimark, The Russians in Germany, 25-34.

50 Foitzik (ed.), Inventar. 
51 'Stellenplan von 1945', 'Stellenplan von 1946', 'Stellenplan vom Feb.1947', 'Stellenplan von 1949', all in Tatjana W. Zarewskaja-Djakina, 'Abteilung Gesundheitswesen', in Jan Foitzik et al. (eds.), SMAD-Handbuch: Die Sowjetische Militäradministration in Deutschland 19451949 (Munich, 2009), 446-55.

52 Wilhelm Weiß, Das Gesundheitswesen in der sowjetischen Besatzungszone, Bonner Berichte as Mittel- und Ostdeutschland (Bonn, 1957). Anna-Sabine Ernst, 'Die beste Prophylaxe ist der Sozialismus': Ärzte und medizinische Hochschullehrer in der SBZ/DDR, 19451961 (Berlin, 1997), 11.

53 Foitzik et al. (eds.), SMAD-Handbuch.

54 This was noted with disdain by some British and American officials, e.g. TNA, FO 371/46733, Political Intelligence Department to Foreign Office, “ "Free Germany” Committee members in governments of Brandenburg, Mecklenburg and Saxony', 10 July 1945.

55 Naimark, The Russians in Germany, 42. In spring 1945 the KPD leadership in Berlin had around 50 émigré communists at their disposal and around 100 re-educated POWs, see Keiderling, 'Gruppe Ulbricht', 35.

56 Kai Schoenhals, The Free Germany Movement: A Case of Patriotism or Treason? (London, 1989), esp. $129 \mathrm{ff}$.

57 e.g. Wolfgang Kohlhaase's film Ich War Neunzehn (1968) depicts the journey of a 19-year-old German son of German émigré communists in Moscow, who accompanied the Red Army on their way to Berlin. The film is based on the autobiographical account of the East German filmmaker Konrad Wolf, whose father, the writer Friedrich Wolf, had emigrated to Moscow with his family. See e.g. Marc Silberman, 'The Filmmaker Konrad Wolf', New German Critique, 49 (Winter 1990), 163-91. Holger Südkamp, 'Ich War Neunzehn: zur filmischen und politischen Bedeutung von Konrad Wolf's DEFA-Film', Europäische GeschichtsdarstellungenDiskussionspapiere, 2/3 (2005).

58 e.g. Berliner Zeitung, 7 July 1945, quoted in Keiderling, 'Gruppe Ulbricht', 50.

59 LAB, C Rep. 907/03-133, Eduard Mellenthsin, 'Zur Situation nach der Befreiung', 18 Mar. 1965.

60 LAB, C Rep. 131/02-02, Protokoll der am 26.November 1945 stattgefundenen Bezirksamtssitzung, 26 Nov. 1945.

61 LAB, Magistrat Verordnung 1 June 1945. Also see the Magistrat's 'Status über die Organisation der Haus-, Straßen- und Blockobleute im Rahmen der Selbstverwaltung der Stadt Berlin', Sept. 1945, in Senat von Berlin (eds.), Berlin-Quellen und Dokumente, 1945-1951 (West Berlin, 1964), 239 ff.

62 LAB, B Rep. 012/902-5, 'Verordnung über die Bekämpfung übertragbarer Krankheiten, 1.6.1945', 14 June 1945. C Rep. 118-40, Magistrat der Stadt Berlin, Abteilung für Gesundheitsdienst, Hauptgesundheitsamt, 8 Aug. 1945. Also see instructions by the ZVG, e.g. 'Verordnung über den Aufbau des öffentlichen Gesundheitswesens: Bekämpfung übertragbarer Krankheiten' of 17 Sept. 1945, repr. in Das Deutsche Gesundheitswesen, 28 (1946).

63 LAB, B Rep. 012/902-5, 'Niederschrift über die Dienstbesprechung mit den Amtsärzten und leitenden Ärzten der Berliner Gesundheitsämter am Donnerstag, dem 14. Juni 1945, in der Universitätsklinik der Charité'. B Rep. 012/902-27, Amtsartz und Leiter des Gesundheitsamtes Schöneberg, 'Anordnung vom 18.6.45 über den zahlenmässigen Nachweis der bekanntgewordenen Infektionsmeldungen in den Bezirksgesundheitsämtern', 21 June 1945. B Rep. 012/902-27, Gesundheitsamt Bezirk Wedding to Magistrat der Stadt Berlin, Abteilung Volksbildung, Presseamt, 21 June 1945.

64 e.g. LAB, C Rep. 131/03-02, Mostroph (Strassenobmann), 'Meldung betr. Volksgesundheitsbund der NSDAP', 26 Jan. 1946.

65 The system of elders was banned in the American sector on 18 Sept. 1945, and in the British sector on 12 Oct. 1945. Keiderling, 'Gruppe Ulbricht', 52.

66 BAB, Z47F, 7317/57/11, Major Rubanov (SMA Brandenburg) on work of the Soviet Health Department in Brandenburg in Nov. 1945.

67 On German self-government in public health: a report from Saxony stated that by early Sept. 1945 'the German organs of selfgovernment had created 23 town departments of health, 12 regional departments and 7 mixed (town/region) departments, which entered the system of self-government. The town, district and provincial directorates are constructed according to a definite structure which answers the needs dictated by the German population's need for the provision of medical services on wide democratic principles.' BAB, Z47F, 7317/57/11, monthly report for Nov. 1945 from SMA Saxony Health Department, 19 Dec. 1945.

68 Benz, Deutschland unter alliierter Besatzung, 440.

69 By comparison: the Länderrat was established in the American zone on 17 Oct. 1945 as a conference of the state presidents to coordinate the state administrations, with greater powers after 1947. Central German administrations were also formed for the US-UK Bizone in 1947, dealing with food, traffic, economy, finance, and postal services. 
70 BAB, DQ1/2, 'Befehl des Obersten Chefs der Sowjetischen Militär-Administration und Oberkommandierenden der sowjetischen Besatzungstruppen in Deutschland, den 27. Juli 1945, Nr.17', signed by Marshall Zhukov, Lieutenant-General Bokov, Colonel Kurasov, Lieutenant Ognev.

71 On the German medical achievements to be learnt by Soviet specialists, see e.g. BAB, Z47F, 7317/56/23, Kuznetsov (SMAG health department) to Marshall Zhukov, 7 Feb. 1946.

72 One of its responsibilities was planning the distribution of doctors across the zone. By contrast, Benz claims that the 11 central administrations were 'mere supporting organs without their own responsibilities', referenced with a West German PhD thesis from 1967. Wolfgang Benz, Potsdam 1945: Besatzungsherrschaft und Neuaufbau im Vier-Zonen Deutschland (Munich, 3rd edn. 1994$), 132$. Regarding the ZVG, this position cannot be supported; also compare to Ernst, 'Die beste Prophylaxe', 28-9.

73 e.g. on social security and insurance policy, see Udo Schagen, 'Kongruenz der Gesundheitspolitik in der Sowjetischen Besatzungszone?', in Wolfgang Woelk and Jörg Vögele (eds.), Geschichte der Gesundheitspolitik in Deutschland: Von der Weimarer Republik bis in die Frühgeschichte der 'doppelten Staatsgründung’ (Berlin, 2002), esp. 400.

74 Paul Weindling, Nazi Medicine and the Nuremberg Trials: From Medical War Crimes to Informed Consent (London, 2004), 31-2.

75 e.g. on a list of tasks for Feb. 1946, one was the 'Characterisation of the German doctor cadres on the basis of an examination of 8500 questionnaires' Z47F, 7317/56/23, plan from Kuznetsov, 17 Jan. 1946. See also BAB DQ1/92, 'Fragebögen für sämtliche Heilberufe', [undated].

76 BAB, DQ1/93, Aktennotiz, 18 Mar. 1946.

77 BAB, Z47F, 7317/57/11, monthly report for Nov. 1945, from SMA Saxony health department, 19 Dec. 1945.

78 BAB, Z47F, 7317/56/23, Kuznetsov report for Dec. 1945, 23 Jan. 1946.

79 'Arbeitsdienstverpflichtete', BAB, DQ1/1338, Diskussion zum Referat Dr Leo, 'Massnahmen gegen Pg.-Ärzte, Ausbildungs- und Prüfungsangelegenheiten der Angehörigen der Heilberufe, die durch den Faschismus verfolgt waren', 3.Tagung der Leiter der Landesund Provinzialgesundheitsämter am 11.11.45.

80 'Arbeitsdienstverpflichtete', BAB, DQ1/1338.

81 BAB, Z47F, 7317/56/23, Kuznetsov's report for Dec. 1945, 23 Jan. 1946.

82 Paul Weindling, 'Heinrich Zeiss, Hygiene and the Holocaust', in Dorothy and Roy Porter (eds.), Doctors, Politics and Society: Historical Essays (Amsterdam, 1993), 181.

83 Hans Harmsen, Gesundheitspolitische Organisation in der DDR und im Ostblock: Zur Entwicklung und Organisation des Gesundheitswesens in der DDR unter Mitberücksichtigung der UdSSR und osteuropäischer Volksdemokratien (Hamburg, 1975).

84 Ruth Mattheis has claimed the opposite, Ruth Mattheis, 'Der öffentliche Gesundheitsdienst in der Nachkriegszeit: Reorganisation und zukunftsorientierte Ansätze', in Akademie für öffentliches Gesundheitswesen in Düssldorf (eds.), 50 Jahre Gessetz über die Vereinheitlichung des Gesundheitswesens (Düsseldorf, 1984), 43-4.

85 BAB, DQ1/93, Deutsche Zentralverwaltung für das Gesundheitswesen, ‘Ärzte-Planung’ [undated, autumn 1945]. DQ1/93, Präsident des Landes Mecklenburg-Vorpommern, 'Verordnung Nr. 130, betr. die Einberufung von Ärzten und anderen Angehörigen der Heilberufe zu fachlichen Dienstleistungen', 26 Sept. 1946.

86 BAB, DQ1/1338, 3.Tagung der Leiter der Landes- und Provinzial-Gesundheitsämter vom 10. November 1945.

87 BAB, DQ1/1338, 3.Tagung der Leiter der Landes- und Provinzial-Gesundheitsämter vom 10. November 1945.

88 Compare Mary Fulbrook, The Two Germanies, 1945-1990: Problems of Interpretation (London, 1992), 64.

89 BAB, DQ1/93, letter to Schölmerich, 22 July 1946.

90 e.g. LAB, C Rep. 118-584, Dr H. Graass, 'Darstellung meiner Arbeit als Ärztlicher Direktor im Waldhaus Charlottenburg', [undated].

91 LAB, B Rep. 012/902-5, 'Bericht über die von der Abteilung für Gesundheitsdienst veranstaltete Dienstversammlung der leitenden Ärzte und der Amtsärzte der Berliner Gesundheitsämter am Donnerstag, den 31.5.1945, 16 Uhr in der Chirurgischen Universitätsklinik der Charité', 14 June 1945.

92 Zhukov's order of 19 Sept. 1945 dissolved the Red Cross in the Soviet zone, and all regional offices were also to be dissolved. But at meetings, German health officers sometimes continued to identify former Red Cross members as such. 
93 BAB, DQ1/1338, meeting of Land and provincial health officers, [19 Sept. 1945], 71.

94 BAB, DQ1/1338, 'Diskussion zum Referat Dr Leo'.

95 BAB, Z47F, 7317/56/23, report from Kuznetsov to Zhukov, 14 Feb. 1946. Heinz Domeinski, 'Zur Entnazifizierung der Ärzteschaft im Lande Thüringen', in A. Thom and H. Spaar (eds.), Medizin im Faschismus (Berlin, 1985), 250-5.

96 Wilhelm Pieck reported that he had received complaints that too many Nazis were still at liberty, and had even acquired administrative posts; complaints particularly concerned Sauerbruch's appointment. 'Gespräch Wilhelm Piecks mit Oberstleutnant K. L. Selesnjow', 26 June 1945, in Keiderling, 'Gruppe Ulbricht', 581-2.

97 BAB, DQ1/1338, 'Protokoll über die Sitzung am 18.9.45', 59, 67.

98 BAB, DQ1/1338, meeting of Land and provincial health officers, [19 Sept. 1945], 71. At the same meeting, Konitzer's proposal to compile a list of antifascist doctors received only a lukewarm welcome.

99 BAB, DQ1/1338, 'Diskussion zum Referat Dr Leo', 148.

100 Leo, BAB, DQ1/1338, meeting of Land and provincial health officers, [19 Sept. 1945], 71. 'Notdienstverordnung vom 15.10.1938' and 'VO zur Sicherstellung der ärztlichen Versorgung vom 27.5.1942', both in Ernst, 'Die beste Prophylaxe', 182.

101 BAB, DQ1/1338, 'Diskussion zum Referat Dr Leo', especially statement of Mössig, 147 ff. Also see DQ1/93, ZVG draft, 16 Oct. 1945.

102 BAB, DQ1/93, ZVG to LGA Saxony, Thuringia, Mecklenburg, Provinzialgesundheitsamt Sachsen and Brandenburg, 29 Dec. 1945.

103 BAB, DQ1/1338, meeting of Land and provincial health officers, [19 Sept. 1945], 71.

104 BAB, Z47F, 7317/57/11, Major Rubanov (SMA Brandenburg), on work of SMA health Brandenburg in Nov. 1945. Z47F, 7317/57/11, Landesgesundheitsamt Thüringen to SMA Thüringen, 14 Dec. 1945, ‘betr. Monat November 1945’.

105 BAB, DQ1/92, ZVG to Provinzialverwaltung der Mark Brandenburg (Abteilung für Gesundheitswesen, Potsdam), 21 Dec. 1945.

106 BAB, DQ1/92, ZVG to Dr Amschler, 28 Dec. 1945.

107 BAB, DQ1/93, ZVG minute, 18 Mar. 1946. Ernst, 'Die beste Prophylaxe', 128.

108 BAB, DQ1/93, Memorandum from Poelz [?] to Leo, Hess, Gysi, 16 Oct. 1945.

109 BAB, DQ1/93, Hermann Redetzky (President of Mecklenburg-Vorpommern health office), to LGA Thüringen and Sachsen, and ZVG, 16 May 1946.

110 BAB, DQ1/1338, ‘3.Tagung der Leiter der Landes- und Provinzial-Gesundheitsämter vom 10.November 1945’, 117.

111 BAB, DQ1/1338, ‘3.Tagung der Leiter der Landes- und Provinzial-Gesundheitsämter vom 10.November 1945’, 117.

112 BAB, DQ1/93, LGA Thüringen an SMA Thüringen, 28 Nov. 1945. Ernst, 'Die beste Prophylaxe', 159.

113 BAB, DQ1/93, memo to Fritz Leo, 14 Nov. 1945.

114 BAB, DQ1/1338, 'Besprechungsniederschrift über die Sitzung der Leiter aller Provinzial- u. Landesgesundheitsämter der sowjetischen Okkupationszone in der Zentralverwaltung für das Gesundheitswesen am 2. Oktober 1945’.

115 BAB, DQ1/182, 'Protokoll der Tagung der Personalreferenten der LGA am 21.12.1946'.

116 BAB, DQ1/93, 'An alle Ärzte!' [undated].

117 Hans Mahle, ‘Aus unveröffentlichen Erinnerungen', 1988, in Keiderling, 'Gruppe Ulbricht', 721. In their memoirs, both Mahle and Walter Ulbricht claim to have approached and recruited Sauerbruch independently, and it is not clear who actually talked to him.

118 BAB, Z47F, 7317/56/23, Kuznetsov to Zhukov, 14 Feb. 1946.

119 This passage was underlined. Z47F, 7317/57/11, monthly report for Nov. 1945 from SMA Saxony health department, 19 Dec. 1945. The VD problem was top of the list in Z47F, 7317/57/11, report for Nov. 1945, on state of health services in Saxony, Serkova, 20 Dec. 1945, signed also by Morosov.

120 Z47F, 7317/56/23, Kuznetsov letter to Zhukov, 7 Feb. 1946.

121 LAB, B Rep 012/902-5, Magistrat health meeting on 8 Nov. 1945. 
122 Stefan Kirchberger, 'Public Health Policy in Germany, 1945-1949: Continuity and a New Beginning', in Donald W. Light and Alexander Schuller (eds.), Political Values and Health Care: The German Experience (Cambridge, Mass., 1986), 204. Timms, The Politics of Fertility, 37.

123 Andreas Dinter, Seuchenalarm in Berlin: Seuchengeschehen und Seuchenbekämpfung in Berlin nach dem II.Weltkrieg (Berlin, 1999).

124 BAB, DQ1/139, excerpt of SMAG report, 12 Feb. 1946, also 'Massnahmen zur Abstellung noch bestehender Mängel in der Durchführung des Befehls Nr. 030', also quoted in Timms, The Politics of Fertility, 224.

125 BAB, DQ1/2209, Dr Marcusson, 20 May 1951. Timms, The Politics of Fertility, 224.

126 LAB, B Rep. 012/902-5, 'Besprechung der Amtsärzte am Donnerstag, d. 22.11.1945'.

127 Plievier, Berlin, 243.

128 Z47F, 7317/57/11, monthly report for Nov. 1945 from SMA Saxony health department, 19 Dec. 1945.

129 On collecting scientific findings, see BAB, Z47F, 7317/56/21, correspondence about the Soviet investigations of the bacteriological laboratories in the Soviet zone. Also Z47F, 7317/56/21, Sokolov to Smirnov, 8 Dec. 1945. Z47F, 7317/56/21, letter and report from Col. Lebediv and Major Kiktjenka to Deputy Commander of the Department of Internal Affairs of the SMAG (Colonel Lapjenkov), 5 Oct. 1945.

130 Z47F, 7317/56/23, report from Kuznetsov to Zhukov, 7 Feb. 1946.

131 Z47F, 7317/56/23, Kuznetsov to Zhukov, 7 Feb. 1946.

132 Naimark, The Russians in Germany, 26.

133 BAB, DQ1/1524, 'Straffe Organisation des Gesundheitsschutzes: unfassende Vorbeugungsmaßnahmen der Sowjetischen Militärverwaltung', Der Morgen, 31 Oct. 1945.

134 BAB, DQ1/1612, DZG to Colonel Sokolov, 23 Aug. 1946.

135 BAB, DQ1/1338, '3.Tagung der Leiter der Landes- und Provinzial-Gesundheitsämter in der sowjetischen Besatzungszone, 10.11.45'.

136 BAB, DQ1/92, Dr med. H. Bendixen to Provinzialgesundheitsamt Halle, 27 Oct. 1946.

137 BAB, DQ1/1634, Max Klesse to Walter Ulbricht, 22 May 1945.

138 BAB, DQ1/1634, memorandum by Max Klesse, 1 July 1945.

139 BAB, Z47F, 7317/56/23, report from Kuznetsov to Zhukov, 14 Feb. 1946.

140 Naimark, The Russians in Germany.

141 Alexandr Fjodorovich Kabanov (Deputy to the Chief for Civil Affairs, SMAG), quoted in Foitzik in Hilger, Schmeitzner, and Vollnhals (eds), Sowjetisierung oder Neutralität?, 109.

142 BAB, e.g. Z47F, 7317/56/21, Serkova (Commander of health sector of SMAG Saxony) to Kuznetsov, 21 Dec. 1945, stated that she would order the Germans to send information on how the German hospitals were organized, run, and managed.

143 BAB, Z47F, 7317/57/11, monthly report for Nov. 1945 from SMA Saxony Health Department, 19 Dec. 1945.

144 In the files, a regular pattern was that the German provincial authorities contacted the ZVG with queries or demands; the ZVG then went to the Soviet authorities in Berlin, who in turn sent directives to their regional Soviet officers, e.g. BAB, DQ1/182, 'Protokoll der Tagung der Personalreferenten der LGA am 21.12.1946'. Also see Ernst, 'Die beste Prophylaxe'.

145 LAB, B Rep. 'Bericht über die Dienstbesprechung am Donnerstag', 4 Oct. 1945.

146 BAB, DQ1/1338, 'Bespechungsniederschrift über die Sitzung der Leiter aller Provinzial- u. Landesgesundheitsämter der sowjetischen Okkupationszone in der Zentralverwaltung für das Gesundheitswesen am 2.Oktober 1945', 11.

147 BAB, Z47F, 7317/56/21, Sokolov (SMAG health department) to Koslenkov (Commander of health of the province of Saxony), 26 Dec. 1945.

148 Tjulpanow, Deutschland nach dem Kriege. 


\section{Figures}

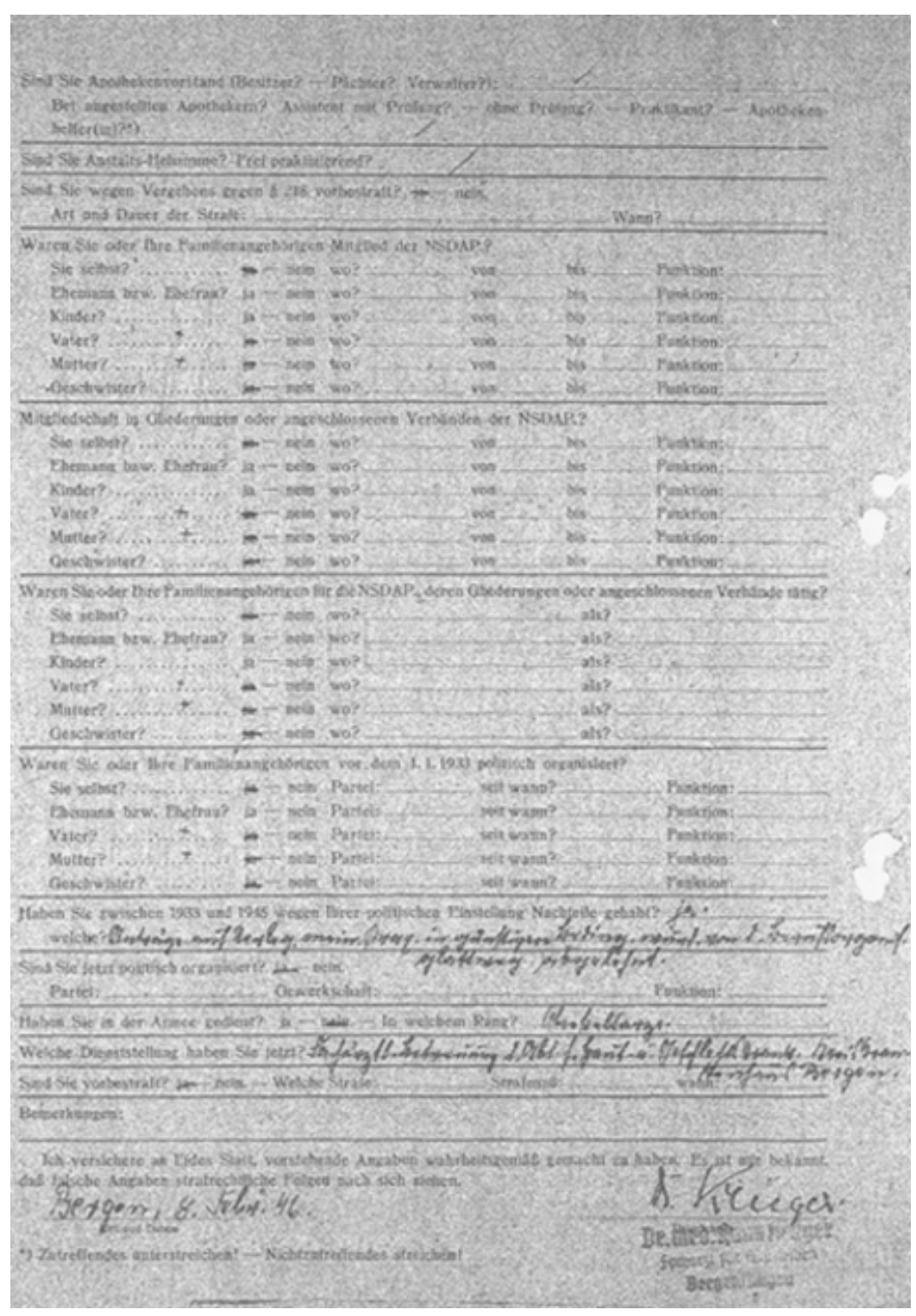

\section{Figure 7.1.}

Questionnaire for medical professions, Soviet zone [February 1946]

This material is not covered by the Creative Commons licence terms that govern the reuse of this publication. For permission to reuse please contact the rights holder directly. 


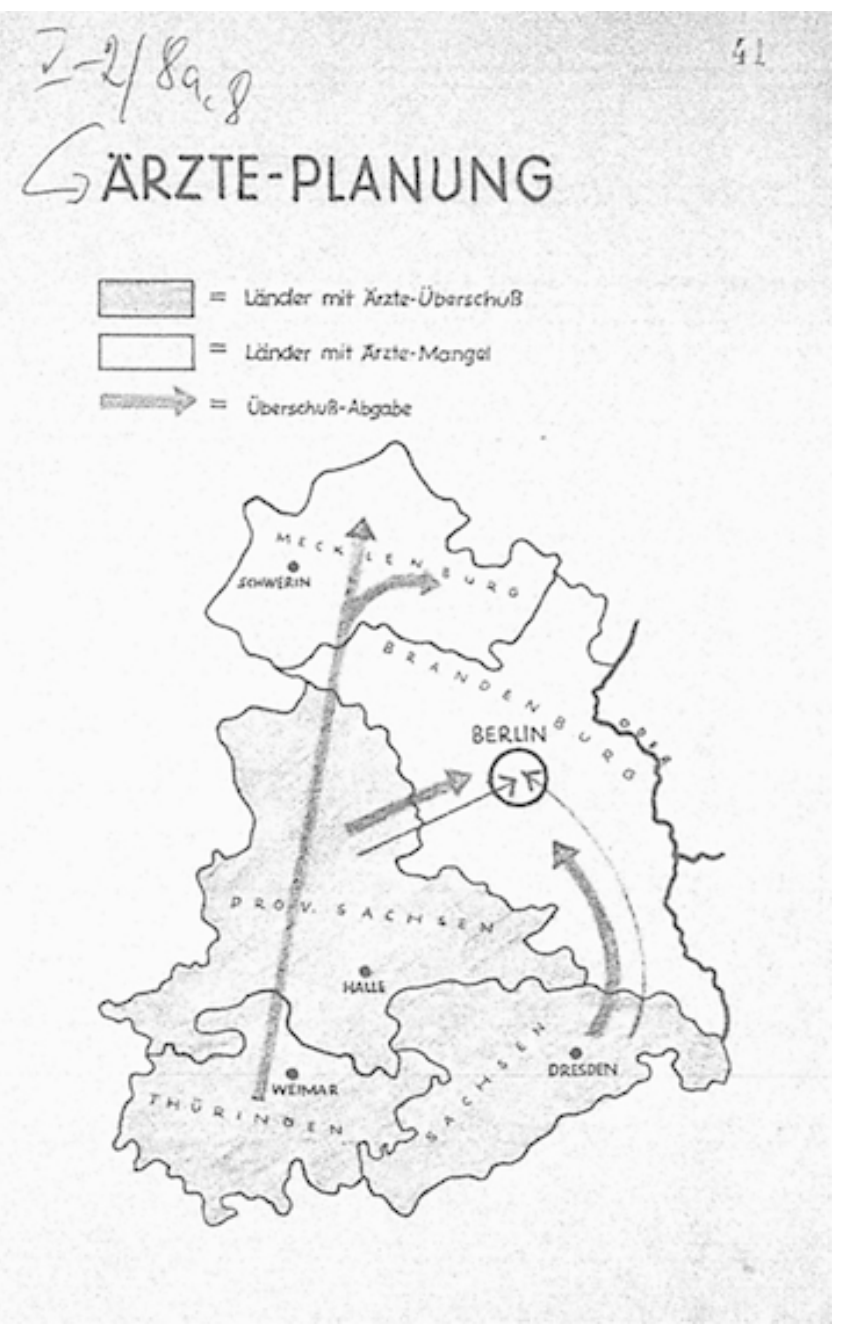

\section{Figure 7.2.}

‘Ärzte-Planung’, map for redistribution across the Soviet zone, 12 December 1945

This material is not covered by the Creative Commons licence terms that govern the reuse of this publication. For permission to reuse please contact the rights holder directly.

(C) Jessica Reinisch 2013.

This is an open access publication. Except where otherwise noted, this work is distributed under the terms of a Creative Commons AttributionNonCommercial- NoDerivatives 4.o International licence (CC BY-NC-ND), a copy of which is available at http://creativecommons.org/licenses/by-ncnd/4.0/ Enquiries concerning use outside the scope of the licence terms should be sent to the Rights Department, Oxford University Press, at the above address.

Monographs, or book chapters, which are outputs of Wellcome Trust funding have been made freely available as part of the Wellcome Trust's open access policy

Bookshelf ID: NBK293858 